\title{
42. BASIN GENESIS IN THE PHILIPPINE SEA
}

\author{
Daniel E. Karig, Department of Geological Sciences, Cornell University, Ithaca, New York
}

\section{INTRODUCTION}

The Philippine Sea forms most of one of the world's two major complexes of marginal basins. Initial analysis (Karig, 1971b) suggested that this region represented a simpler mode of evolution than did the Melanesian complex and that it would provide an opportune area in which to investigate the basic nature of island arcforming processes. It was largely to test this rationale that a number of recent oceanographic cruises and Leg 31 of the Deep Sea Drilling Project were conducted in the region (Figure 1).

Synthesis of the data accumulated thus far only partly bears out this assumption of simplicity. East of the Palau-Kyushu Ridge, the Philippine Sea does appear to be a simple eastward progression of sequentially younger basins, as previously postulated (Karig, 1971a, b). The additional data have more closely resolved the time of origin and clarified the relation of extensional pulses to other arc-related activity. The basins west of the Palau-Kyushu Ridge, however, do not represent a simple extrapolation of the process active to the east. In that region there are hints of arc polarity reversals, collisions, and other reorganizations of tectonic elements. With the present paucity of data, only speculations concerning the origin of the western region can be hazarded.

\section{EASTERN AREA}

Four basins or extensional zones comprise the Philippine Sea complex east of the Palau-Kyushu Ridge. Behind the Bonin arc are the presently active extensional zone within the Iwo-Jima Ridge and the inactive Shikoku Trough. Behind the Mariana arc are the active Mariana Basin and the inactive Parece Vela Basin which merges to the north with the Shikoku Basin. Only the Shikoku Basin was drilled during Leg 31, but DSDP Holes 53 and 54 (Fischer, Heezen, et al., 1971) were drilled in the Parece Vela Basin.

Tracks of Glomar Challenger from DSDP Legs 6 and 31 and unpublished data from SIO and NOAA cruises will be used to construct a history of all these basins. To review the process of inter-arc extension and to develop a consistent discussion, the basins will be described from east to west, beginning with the Mariana Trough which has been more extensively investigated (Karig, 1971b; Bracey and Ogden, 1972; Karig and Anderson, in preparation).

\section{Mariana Trough}

The Mariana Trough is approximately half-moon shaped, open at the complex south end and closing at the junction of the Bonin and Mariana arc systems (Figure 1). Its extensional origin has been corroborated since an initial study (Karig, 1971b) by: (1) recovery of recent tholeiite from the basin axis (Hart et al., 1972); (2) an axial band of high heat flow (R. N. Anderson, personal communication); and (3) a subjacent mantle zone of high seismic wave attenuation (Barazangi et al., in press). Extension appears to be approximately symmetrical, along a band some $40 \mathrm{~km}$ wide (e.g., Figure 2), but the details of the process remain unclear. In areas where the topography is known in sufficient detail, it consists of ridges which appear to be tilted fault blocks, which trend north regardless of the trend of the flanking ridges (Figure 1). This invariant trend does not appear to be an inherited inhomogeneity and suggests that spreading is uniformly east-west. East-westtrending fractures have been identified in the basin (Karig, 1971b), but their origin and tectonic role is not clear. Extension in the basin does not appear to result from a rigid rotation around a single pole (Karig and Anderson, in preparation). Neither is there evidence that the basin opened in segments along fractures extending from the trench to the extensional zone (Bracey and Ogden, 1972).

The sediments in the basin are ash-rich hemipelagic silts and clays except near the volcanic chain, where a volcaniclastic apron is forming (Karig, 1971b). Although the hemipelagic sediments are less than 200 meters thick except in local ponds where redeposition has occurred (Figure 2), sedimentation rates, based on similar lithologies in the similar Lau Basin (Burns, Andrews, et al., 1973), approach $100 \mathrm{~m} / \mathrm{m} . y$. These sediment data and the Plio-Pleistocene silicic volcanism on the West Mariana Ridge, which may mark basin initiation (Karig and Glassley, 1970), indicate that the basin began opening no more than $3 \mathrm{~m} . \mathrm{y}$. ago, and very possibly more recently.

\section{Bonin Zone}

The Bonin arc system possesses an anomalously broad frontal arc, which consists of northeast-trending en-echelon ridge segments. This segmentation, for the most part, is a result of earlier tectonism (Karig and Moore, in preparation), but several small closed basins with recent basaltic floors (Karig, 1971b) attest to a minor amount of contemporary extension. There are insufficient data to determine whether or not this extension can be considered a rigid rotation. It is surmised that extension is in an east-west direction along the entire arc (Karig and Moore, in preparation), rather than northwest-southeast as previously suggested (Karig, 1971b). The duration of extension is equally obscure. Historic silicic volcanism on a subsidiary volcanic chain west of the andesite-basaltic line (Tsuya, 1937; Kuno, 1962 ) is probably analogous to the dacitic volcanism on 


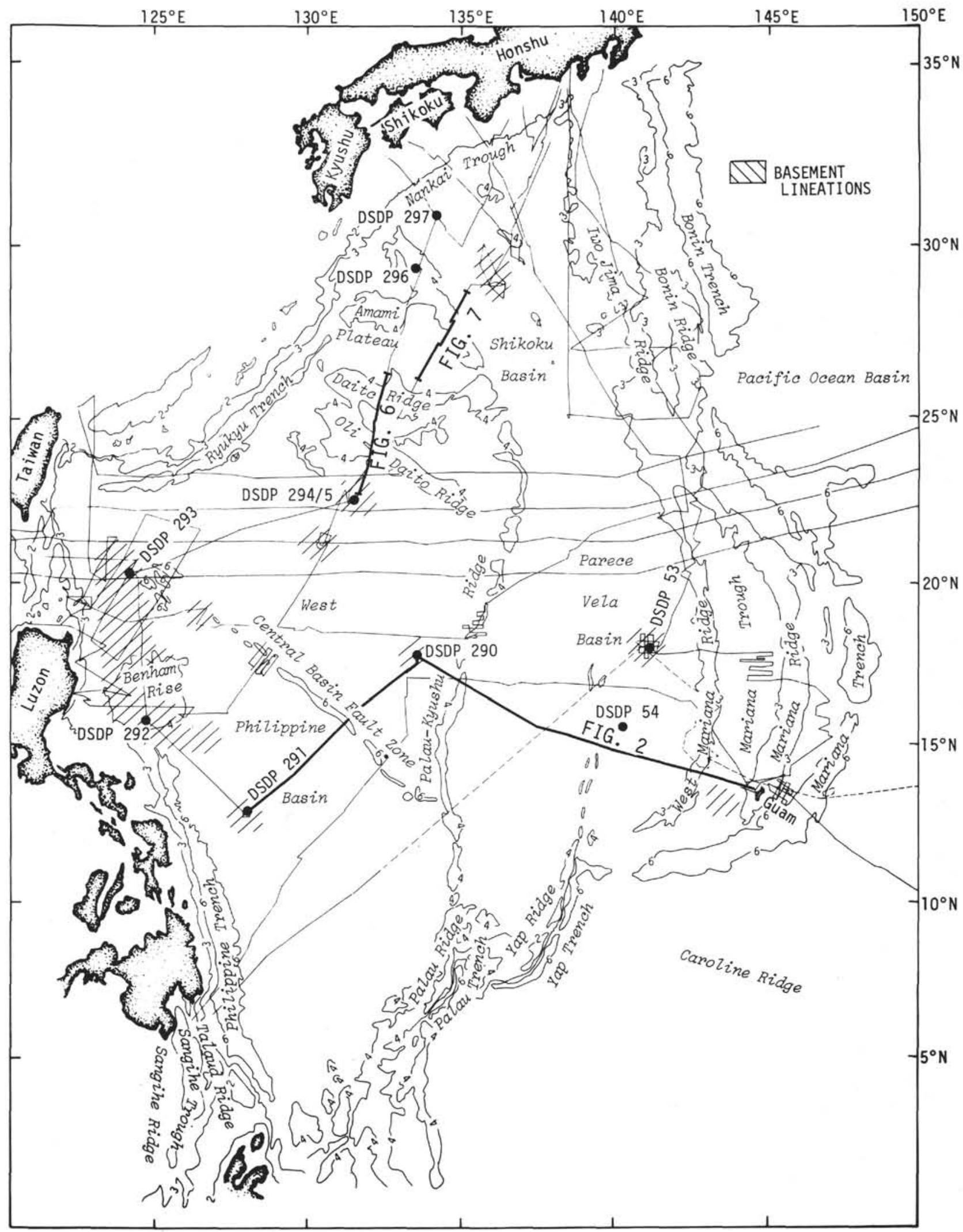

Figure 1. Outline map of the Philippine Sea region showing bathymetric features and basement lineation directions discussed in text. Oceanographic ship tracks along which data used in this paper were collected are also indicated. 
the West Mariana Ridge (Karig and Glassley, 1970) and might suggest a younger extensional pulse than in the Mariana arc.

\section{Parece Vela Basin}

Except for its greater size and depth, the Parece Vela Basin has characteristics that are very similar to those of the Mariana Trough. A very large volcaniclastic apron fills the eastern half of the basin, and thin pelagic deposits cover the remainder (Figures 2 and 3 ). Rapidly deposited hemipelagic clays, similar to those of the Mariana Trough, were probably deposited early in the basin history. However, sedimentation rates apparently dropped as the basin widened and further decreased to 3 $\mathrm{m} / \mathrm{m}$.y. or less following cessation of the volcanic pulse in late middle Miocene.

Symmetrical spreading from an axial zone is suggested by an axial zone of great relief, which is interpreted as marking the final position of the spreading zone (Karig, 1971b). Termination of extension, if symmetric, was in the early Miocene because the basement at DSDP Sites 53 and 54 (Fischer, Heezen, et al., 1971) which were near the axial zone, is most probably of that age. If asymmetric extension occurred along a zone near the volcanic chain, then termination of basin formation must have been even earlier, because the early and mid-Miocene strata of the volcaniclastic apron are not deformed. The date of initiation of extension is not well constrained. Oligo-Miocene brown clay (SIO Proa Core $16 \mathrm{G}$ ) overlying the volcaniclastic apron west of the Palau-Kyushu Ridge, and late Oligocene volcanic ash cored in Hole 290 (Site 290 Report, this volume) above sediments of the same apron could be interpreted as a result of basin initiation in late Oligocene, and abandonment of the Palau-Kyushu Ridge by the volcanic chain before the end of that epoch. The north-northeast trend of basement lineations in the Parece Vela Basin suggests an east-southeast direction of extension.

The zone of high relief that is centrally located in the northern and central sections of the basin continues northward as the Kinan Seamount chain of the Shikoku Basin. However, to the south it departs from an axial position to join the Mariana-Yap arc junction (Figure 1). There are suggestions of a subdued rough zone which does continue southward along the axis of the Parece Vela Basin (Lair and Sanko, 1969).

Although it is suggested that the axial section of the very rough zone marks the final extensional zone position, the section of greatest relief, from Yap to about $15^{\circ} \mathrm{N}$, may have resulted from displacement subsequent to basin extension. This zone has slightly en-echelon segments, and a morphology quite similar to the Central Basin Fault of the West Philippine Basin (SIO Core Ant 213P), containing very late Miocene calcareous ooze (J. C. Bukry, personal communication). This ooze, from a shallow ridge top along this zone, provides the minimum age of this relief because the normal basin sediments of this age are brown clays.

\section{Shikoku Basin}

The Shikoku Basin lies between the Parece Vela Basin and southwest Japan (Figure 1), and because of the in- flux of terrigenous sediments from the north, it contains a thicker sediment cover than the other marginal basins of the eastern Philippine Sea (Figure 3). The terrigenous sediments decrease in thickness southward from Japan and merge with a thin pelagic cover near $25^{\circ} \mathrm{N}$.

The oldest sediments sampled in DSDP Hole 297 (Site 297 Report, this volume) were volcanic-rich clays, deposited above the $\mathrm{CCD}$, and reflecting a substantial material influx from Japan (Chapter 8, this volume). A transition to turbidite deposition in the late Miocene or early Pliocene may mark initiation of strong uplift in Shikoku which has persisted to the present (Matsuda et al., 1967). Termination of turbidite deposition in the mid-Pliocene resulted from the development of the Nankai Trough as a sediment trap (Chapter 8, this volume).

A second source of sediment in the basin has been the volcanic chain along the Bonin Island arc, which has generated a compound volcaniclastic apron (Karig and Moore, in preparation). An older, acoustically opaque apron unit underlies a younger, highly reflective unit and, respectively, probably represent the Miocene and Quaternary volcanic episodes recognized in this area (Sugimura et al., 1963).

The acoustic basement in the Shikoku Basin has characteristics typical of basaltic fault blocks, and where closely examined, is lineated in a north-northwest direction (Figure 1). These topographic lineations are colinear with the magnetic anomalies in the basin (Tomoda et al., 1973; Watts and Weissel, 1974). The lineation trend suggests extension in an east-northeast direction, approximately perpendicular to the flanking ridges. An axial zone of high relief and seamounts (Kinan Seamount chain) may here also mark the terminal position of the extensional zone. One anomalous northeast-trending basement ridge was observed near DSDP Site 297 (Chapter 8, this volume).

The results of DSDP Holes 296 and 297 show reasonably well that the basin began opening during the very late Oligocene, and suggest an early Miocene cessation of extension (Chapter 8, this volume). It thus appears that both the Shikoku and the Parece Vela basins opened simultaneously, and form sections of a single large marginal basin.

\section{WESTERN REGION}

The Philippine Sea west of the Palau-Kyushu Ridge is comprised of the very large West Philippine Basin and, in the northern sector, of a complex of small basins and ridges that has received very little study. Although it is clear that the western region is older than that to the east, it does not seem to have developed in the same straightforward way. Even after the drilling of five DSDP sites in the West Philippine Basin, only suggestions concerning its origin can be made.

\section{West Philippine Basin}

The West Philippine Basin is deeper and older than the eastern basins and has crustal heat-flow values approaching that of old oceanic crust (Watanabe et al., 1970; Sclater, 1972). It is roughly bisected by the Central Basin Fault zone which comprises a band of high relief 


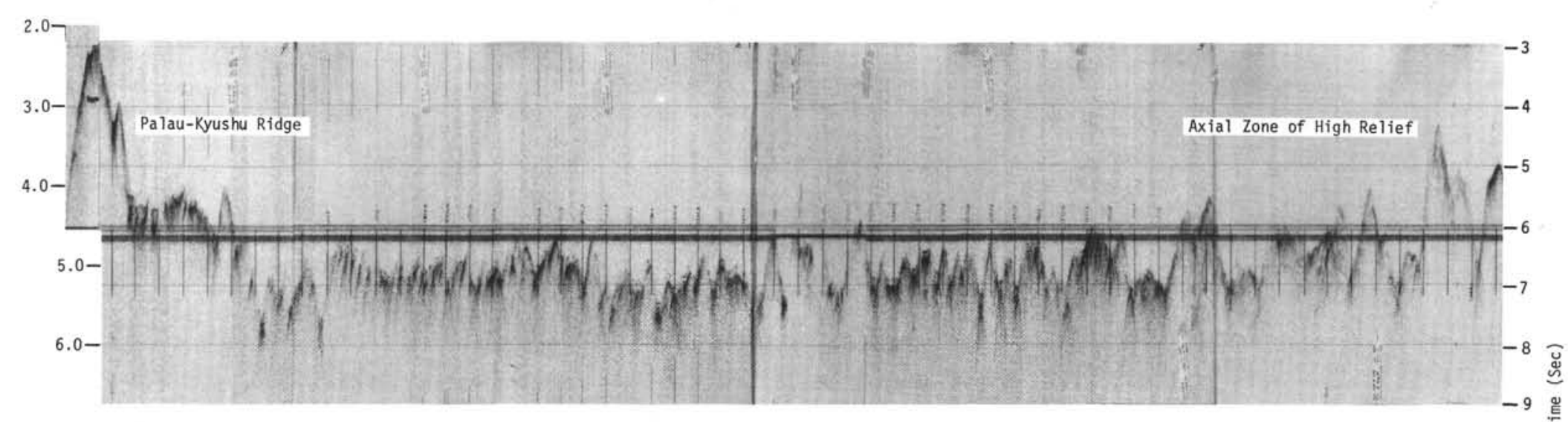

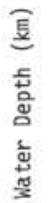

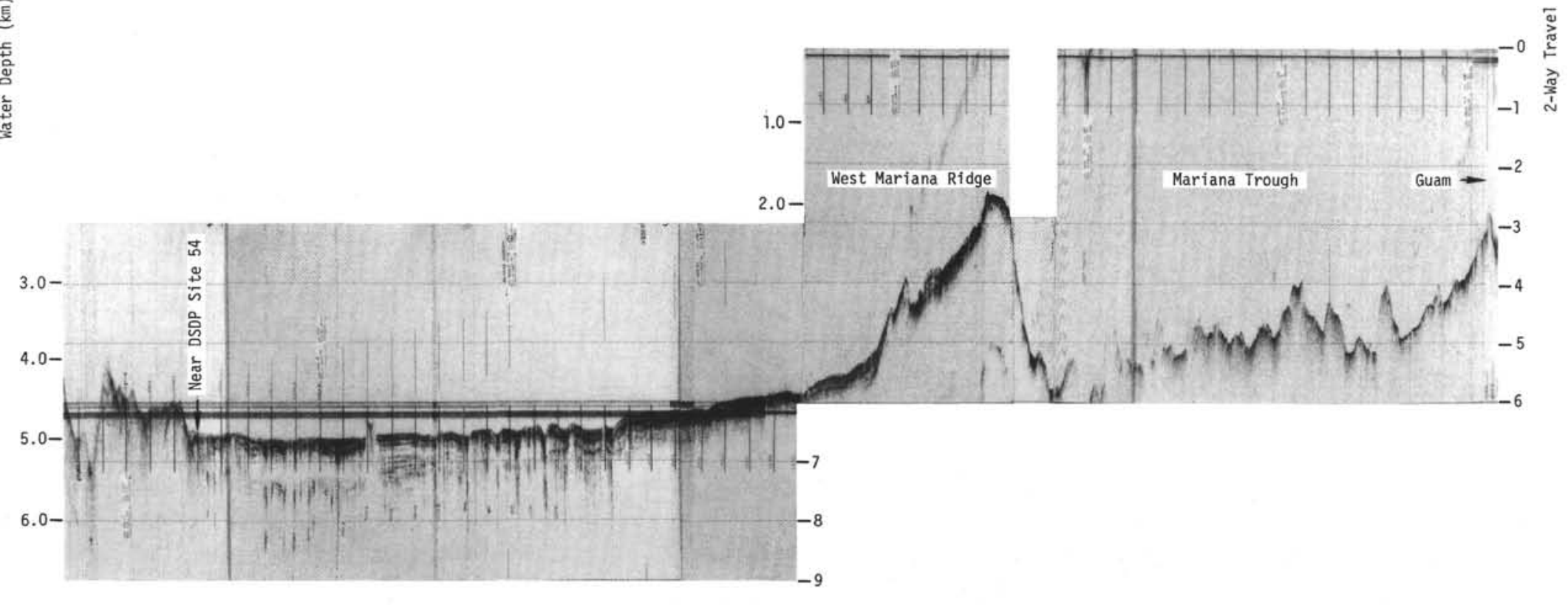

Part A. Mariana Ridge (Frontal Arc) to Palau-Kyushu Ridge (Remnant Arc).

Figure 2. Glomar Challenger Leg 31 seismic reflection profile across the Philippine Sea from Guam to Site 291. (A)(upper) Profile across the Mariana Trough and Parece Vela Basin. Note the axial zones of high relief in both basins and the lack of a westward deepening of basement in the eastern Parece Vela Basin. Both features indicate symmetrical spreading. (B)(lower) Profile across the West Philippine Basin. Note the nature of the Central Basin fault zone and more subdued relief in rest of basin compared to that of the eastern basins. 


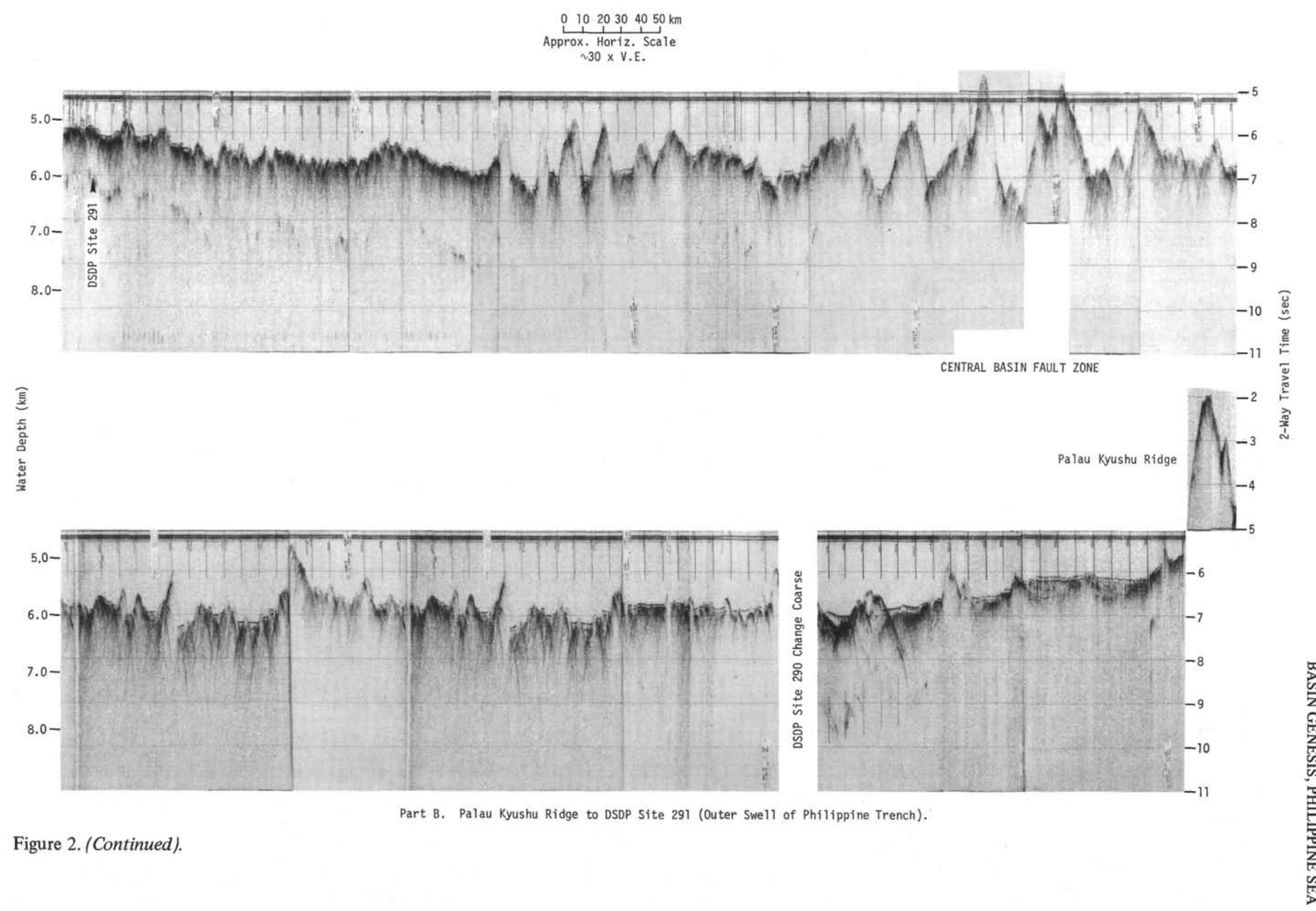




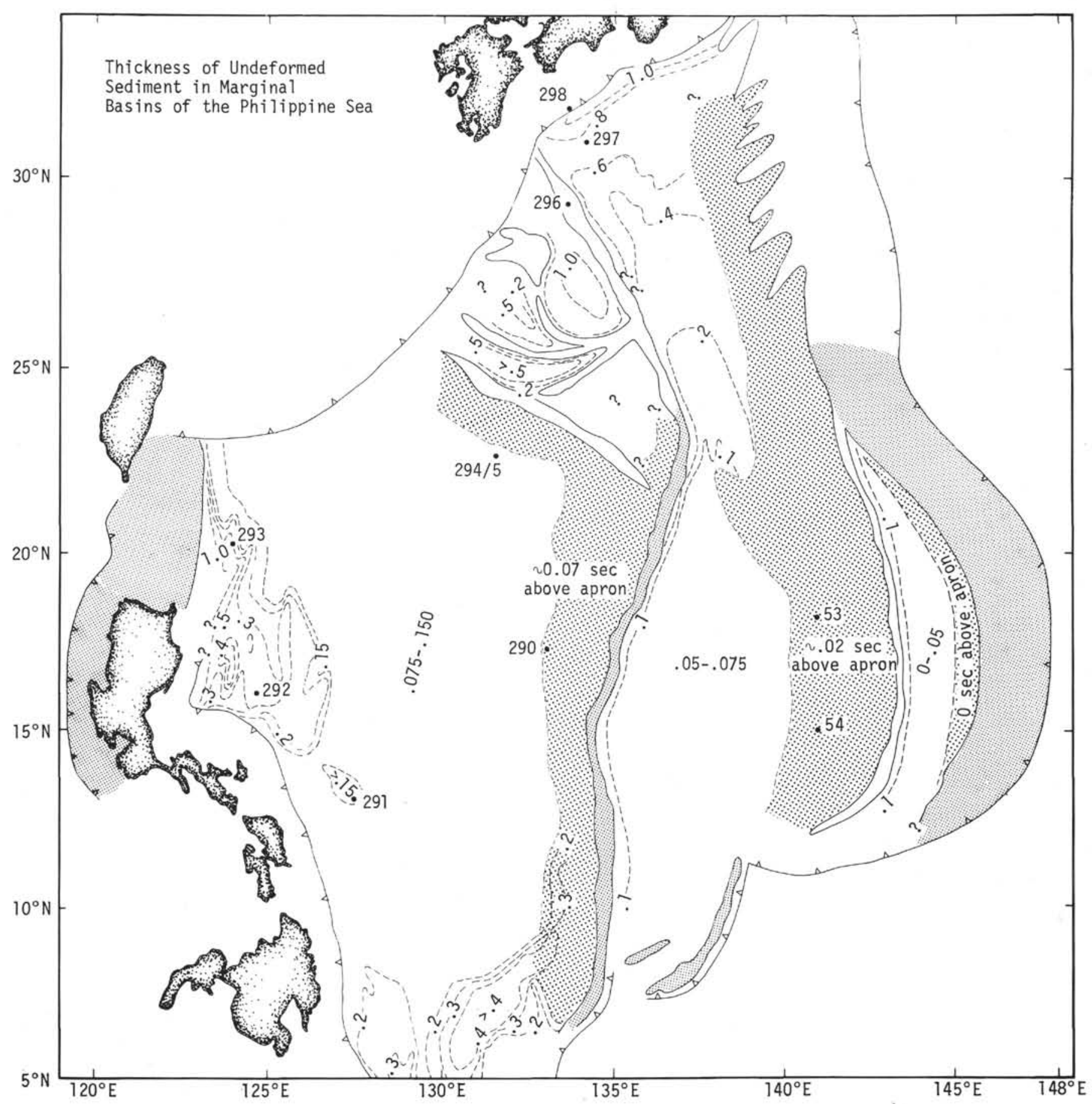

Figure 3. Thickness of undeformed sediments in marginal basins of the Philippine Sea. The largely opaque volcaniclastic aprons, which may reach thicknesses of several kilometers, are shown as heavily stippled areas. In areas of irregular topography and variable sediment thickness, a qualitative average thickness is shown.

running from the northwest corner to the Palau-Kyushu Ridge near $14^{\circ} \mathrm{N}$ (Figure 1). One major problem, the mode of basin formation, has attracted considerable recent attention (Karig, 1971b; Lee and Hilde, 1971; BenAvraham et al., 1972; Uyeda and Ben-Avraham, 1972; Louden, in preparation). Another related question is whether the basin is older than the late Eocene age indicated by the DSDP Leg 31 drill holes in the basin.
This latter point depends upon whether the late Eocene basal sediments and basalt in the basin are underlain by yet older sediments. Older, reworked fossils were recovered at Sites 290, 293, and 294/295 (Chapters 2,5 , and 6 , this volume), but these most likely were derived from the adjacent ridges, which should be older than the basin if it were created by extension. Pelagic sediments and oceanic crustal rocks exposed along the 
southeast coast of Mindanao (Meledres and Comsti, 1951; Ranneft et al., 1960) are late(?) Eocene, and there is no mention of older sediments. Because these sediments probably were deposited in the West Philippine Basin and exposed as a result of arc collision, they add further support to an Eocene age for the original basin crust.

If additional sediments and true basement lay beneath the Eocene basalt, the present total crustal thickness should be thicker than the original crust. Most of this increase should be in the second layer. Refraction results, to the contrary, show a third layer and a second layer that are thinner than that of oceanic crust (Murauchi et al., 1968; Henry et al., this volume). If a low velocity layer in the Philippine Sea were assumed, it would require a thinner original crust than has ever been observed.

Even if the late Eocene origin of the basin is accepted, the geometry of the spreading process remains to be determined. Lack of a sufficient unambiguous spread in basement age among the five DSDP holes precludes determination of any spreading pattern on that basis.

Topographic lineations, which generally mark the trend of extensional ridges and troughs in marginal basins, are known in only a few parts of the basin (Figure 1) and may in part reflect deformation that took place well after the basin formed. Ridge-trough topography in the northwestern sector of the basin, between the Central Basin Fault and the Philippine Trench, and north of about $15^{\circ} \mathrm{N}$, trends north to northnortheast (Figure 1). A similar trend may exist near DSDP Site 290 (Chapter 2, this volume). Possible northwesterly trends were delineated near DSDP Sites 294/295 during SIO Tasaday cruise (Figure 1).

Closely spaced survey tracks across the Central Basin Fault around $18^{\circ} \mathrm{N}$ (Figure 4) demonstrate rather clearly that the trend of the high-amplitude ridges and troughs comprising the zone is north-northeast rather than parallel to the $\mathrm{N} 55^{\circ} \mathrm{W}$ Central Basin Fault trend. A less detailed survey (Figure 5) at $19^{\circ} \mathrm{N}$ indicated the identical relationship.

The topographic expression of the Central Basin Fault northwest of $18^{\circ} \mathrm{N}, 129^{\circ} \mathrm{E}$ thus appears to be a zone of en-echelon, north-south-trending ridges and troughs. Where surveyed, this zone is about $100 \mathrm{~km}$ wide, and seems to merge with the north-south basement trends which dominate the northwestern corner of the basin. No throughgoing feature, identifiable as the Central Basin Fault, can be traced to the East Luzon arc system. Areas of smooth basement preclude the extension of the fault zone to the Taiwan-Ryukyu junction.

Louden (in preparation), working on the southeastern part of the Central Basin Fault, has described a set of low-amplitude magnetic anomalies with a $\mathrm{N} 70^{\circ} \mathrm{W}$ trend. The anomalies southwest of the fault show a reasonable fit within the mid to late Eocene magnetic time scale, but those northeast of the fault are not as well defined. It is not clear from these anomalies whether spreading is symmetric or asymmetric, but in either case, the magnetically predicted dates differ from those determined from the DSDP results by 3 to 10 m.y.
These magnetic anomalies cannot be projected northwestward into the area displaying north-south topographic trends, in part because of sparser data (Louden, in preparation), but there may also be a major difference in spreading geometry in the two areas. The most likely basement ages at DSDP Holes 292, 293, and $294 / 295$ do not fit a simple extrapolation of either the symmetric or asymmetric magnetic pattern of Louden (in preparation).

An additional complexity hindering the reconstruction of the basin origin is the high probability that deformation within the West Philippine Basin, subsequent to basin formation, is responsible for much of the present morphology of the Central Basin Fault. Disrupted pelagic sequences and basement rocks in and around DSDP Hole 293 (Chapter 5, this volume; Karig and Wageman, this volume) suggested that displacement along the north-south ridges occurred after the midEocene and before the Pliocene.

Several seismic reflection profiles (Figure 6) and a recent recontouring (Figure 7) in the area where the Central Basin Fault meets the Palau-Kyushu Ridge indicates that the fault zone in that area splays to a width of several hundred kilometers or more and that the late Eocene to early Oligocene volcaniclastic apron behind the Palau-Kyushu Ridge is displaced. Faulting, rather than ponding of turbidites in troughs with differing depths, is thought responsible for the offsets of the apron because single basin sequences are broken, and because some turbidite sections now occupy ridge crests. A few closely spaced tracks across the fault zone suggest that here, also, the individual troughs are not throughgoing features. However, there are not enough data to determine trends. Location of the tracks used by Louden (in preparation) and of other well-navigated tracks do not support his contention that the topography of the Central Basin Fault trends $\mathrm{N} 70^{\circ} \mathrm{W}$.

It is tentatively concluded that whatever the origin of the Central Basin Fault, its present morphology, and its present $\mathrm{N} 55^{\circ} \mathrm{W}$ trend are a result of mid-Tertiary tectonism in the basin. The en-echelon pattern suggests either right-lateral shear or east-west extension, but in either case, the total displacement need not be more than a few tens of kilometers.

There are other features of the West Philippine Basin that either help constrain modes or dates of origin, or suggest other tectonic events. In this respect, sedimentation patterns are notably useful.

Pelagic sediments cover the entire basin floor and in most areas comprise the total sediment columns. The areas having nontypical sediment sections are discussed separately below. The totally pelagic sediment cover ranges from 75 to 150 meters thick, but there is no discernible systematic variation in that thickness within the basin. Even immediately adjacent to the Central Basin Fault, the sediment cover is of average thickness (Figure $5)$. Because the depositional rate of these brown clays has been $3 \mathrm{~m} / \mathrm{m} . \mathrm{y}$. or less since the early Oligocene (Sites $290,291,294 / 295$ ), this sediment distribution precludes basin extension more recently than about the midTertiary. It also implies a fairly uniform age throughout 


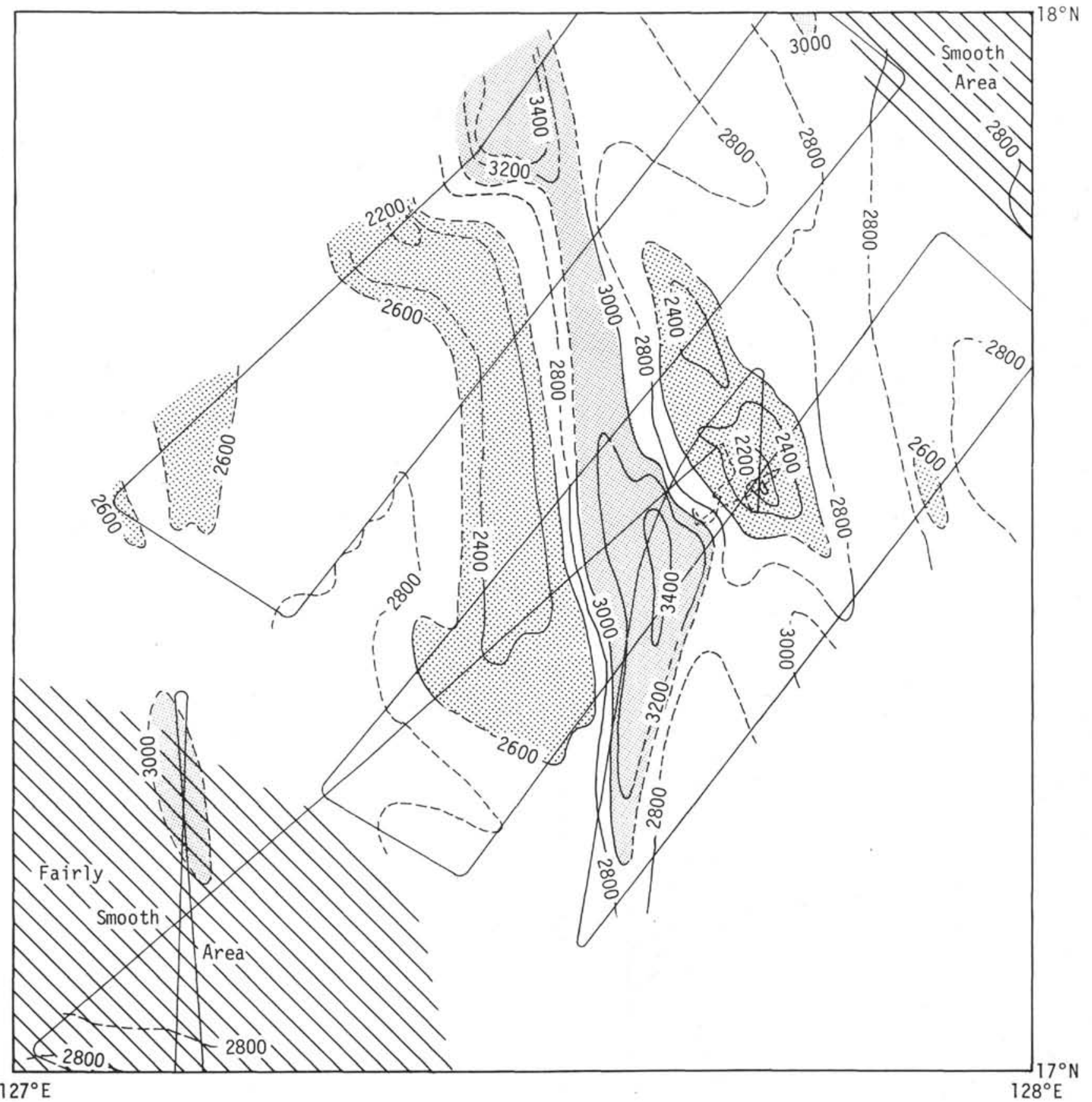

Figure 4. Survey of a section of the Central Basin Fault zone showing the internal north-south-trending en echelon pattern of the high relief topography.

the basin, and is consistent with DSDP basement ages which indicate rapid extension in the late Eocene.

Areas displaying thicker sediments include the Benham Rise, the volcaniclastic apron west of the Palau-Kyushu and Palau ridges, the apron northeast of Luzon, and a zone lying east of the Philippine Trench from the Palau Ridge to about $8^{\circ} \mathrm{N}$. Each of these is evidence of tectonic activity within or around the basin.

The 300 to 400 meter thick pelagic cover over the Benham Rise reflects deposition above the local CCD.
Results from Hole 292 (Chapter 4, this volume) demonstrate that this small mid-plate rise was built of tholeiitic basalt to a very shallow depth by the beginning of the Oligocene (McKee, this volume). There is, however, no evidence of extensive land areas at that time. Subsequently, the rise crest has sunk to its present depth of $3 \mathrm{~km}$ without sign of igneous or substantial structural activity.

The volcaniclastic apron west of the Palau-Kyushu Ridge is evidence of a period of arc-related volcanism 

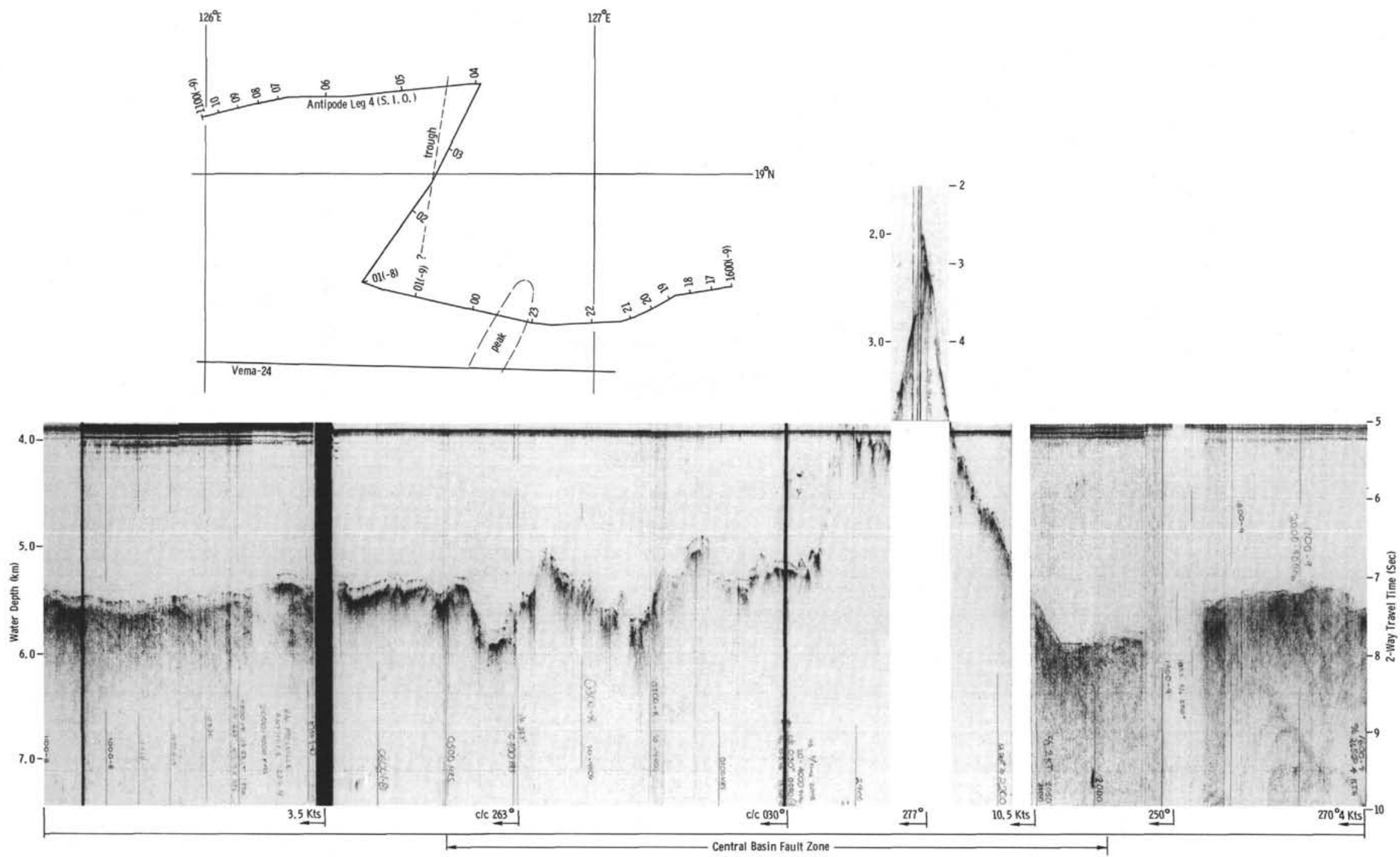

Figure 5. SIO (Antipode Leg 4) seismic reflection profile across the Central Basin Fault zone. This zig-zag track, together with that of LDGO Vema 24 , indicates north to north-northeast-trending internal ridges and troughs within the fault zone. Note the lack of thinning in the pelagic sediments near the fault zone, which precludes mid-or late Cenozoic spreading along the feature. 

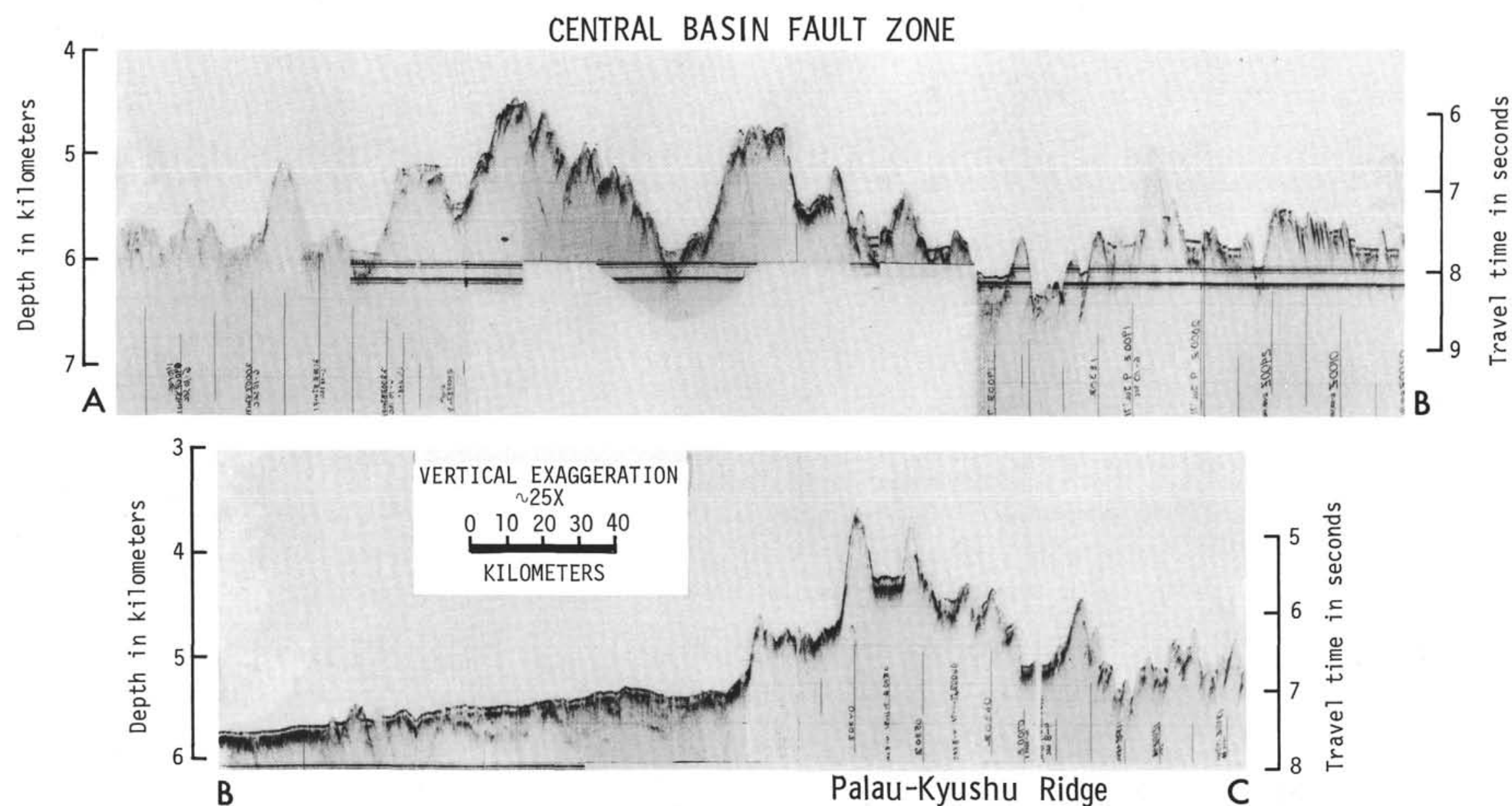

Figure 6. SIO(Antipode Leg 13) seismic reflection profile across the Central Basin Fault zone and Palau-Kyushu Ridge near their intersection (location shown on figure 7). The broken turbidite unit on the upper profile, including sections perched on ridge tops, are cited as evidence for a broad zone of faulting subsequent to the late Eocene-early Oligocene formation of the volcaniclastic apron west of the Palau-Kyushu Ridge. 


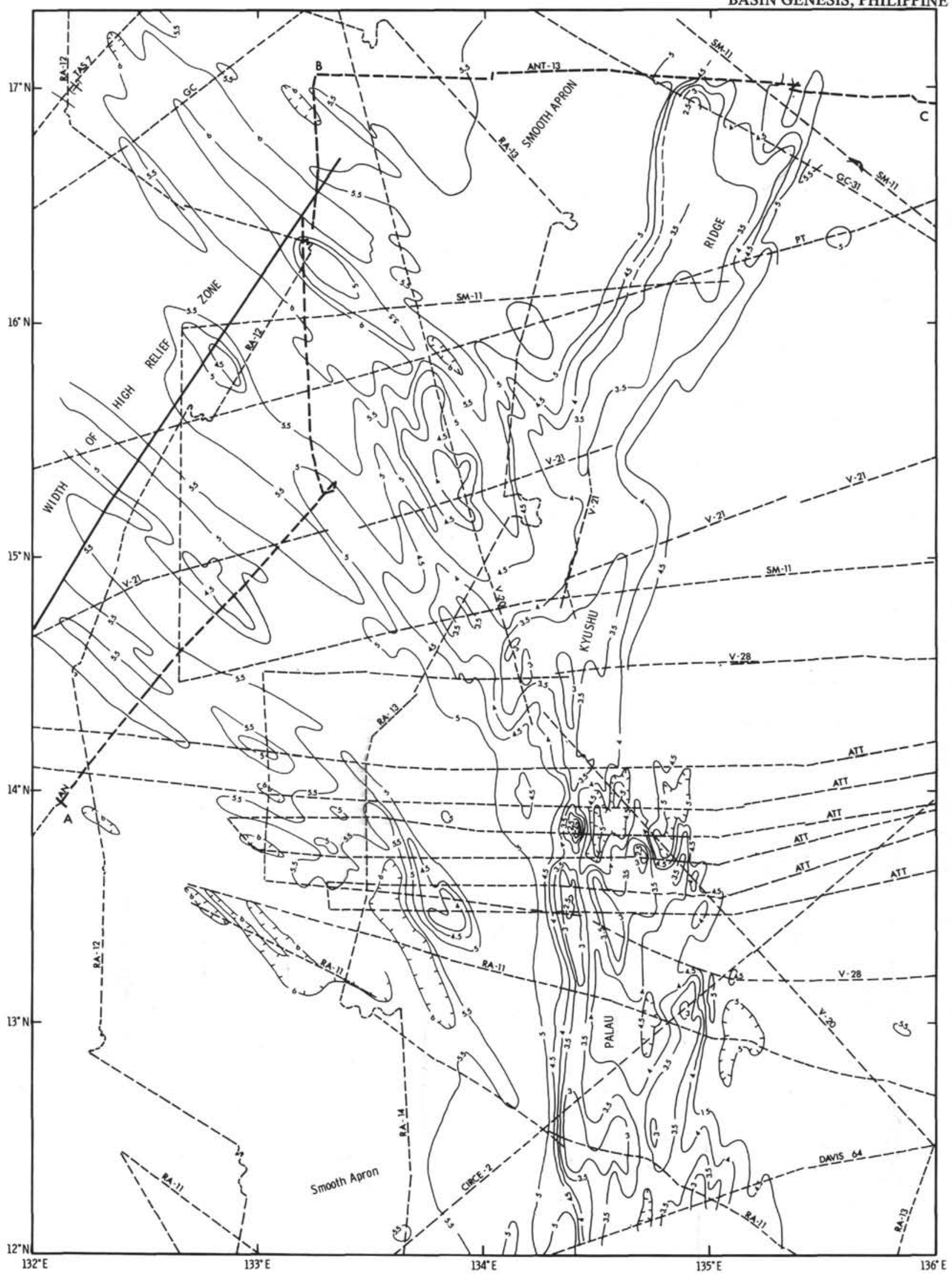

Figure 7. Preliminary bathymetric chart of the region where the Central Basin Fault intersects the Palau-Kyushu Ridge (in corrected $\mathrm{m}$ ). Control between better navigated tracks is from U.S.N.O.O. compilation sheets on file at Scripps Institution of Oceanography. These contours indicate that the Central Basin Fault zone is over $200 \mathrm{~km}$ wide at its intersection with the Palau-Kyushu Ridge, and suggests that the zone is turning southward as it meets the ridge. There is no significant offset of the Palau-Kyushu Ridge, nor any clearcut evidence for the fault zone east of the ridge. 
and subduction during the early Oligocene. Although the older part of the apron was not drilled, the geology of the islands on the present frontal arc, which was then in contact with the Palau-Kyushu Ridge, shows that this volcanism began in the late Eocene or earlier. Part of this history is stored and displayed within the sediments and rocks comprising Guam Island (Ingle, Chapter 41, fig. 5, this volume). Reworked Cretaceous foraminifera in Hole 290 (Chapter 2, this volume) suggest an earlier history for the ridge area, but not necessarily as an arcrelated feature.

A second apron northeast of Luzon is much younger and reflects uplift of Luzon more than it does a pulse of volcanic activity. Poorly constrained faunal evidence from Hole 293 and regional geology (Karig and Wageman, this volume) suggest that the apron began forming when a subduction zone along the east side of Luzon became inactive in the mid-Tertiary. An increase in growth rate and in average grain size near the end of the Pliocene (Chapter 5, this volume) is thought to correlate with strong Quaternary uplift of Luzon (Christian, 1964 ; Ingle, Chapter 41, fig. 4, this volume).

More difficult to explain is the lobe of thicker sediment which flanks the Philippine Trench on the east as far north as $8^{\circ} \mathrm{N}$ (Figure 3). The source of these sediments is most logically from the west or southwest, but the trench now blocks this transport route. This sediment pile ranges from 200 to over 400 meters in thickness and displays the geometry of turbidite deposits (unpublished seismic profiles from U.S. Navy M.G.S. Program 65-67). Two cores from the area (Lair and Sanko, 1969) show coarse, graded volcaniclastics (RA13-7-3) and silty lutites (RA-13-7-2). The first of these was located on the crest of the outer swell of the trench, and both were in areas showing very low relief (unpublished seismic profiles from U.S. Navy M.G.S Program 65-67). It appears that both cores actually sampled the sediments of the lobe. A 1-meter-thick surficial unit of brown clay in another nearby core (LDGOConrad-11-152) suggests that cessation of turbidite deposition was very recent.

It might be argued that the source is along the Palau Ridge, over $400 \mathrm{~km}$ to the south, but there has been no late Tertiary volcanic activity and there are no sources of reworked volcanic debris along that ridge. Clasts in core RA-13-7-3 are altered volcanics with arc affinities and show no rounding (personal observation).

An alternate explanation, that the sediment came from the west (East Mindanao-Talaud Ridge) and that the trench is a very recent feature, is preferred. Bathymetric and seismic reflection profiles across the south Philippine Trench show no accretionary prism and are very similar to those across other very young subduction zones (Karig and Sharman, in press). The pronounced landward displacement of the gravity low associated with the trench (U.S. Department of Commerce, 1969; J. A. Grow, personal communication, 1974) is probably due to low density sediments, but these are deformed and most likely the result of an earlier subduction episode.

The volcanic chain and seismic zone of Central Mindanao seems to be associated with the present Philippine
Trench, but to the south these diverge. The volcanics and the seismic zone follow the Sangihe Ridge (Fitch, 1972 ) and are probably related to a subduction zone in the Molucca Sea. Consistent plate reconstruction requires that the eastern Mindanao-Talaud Ridge be colliding with the western Mindanao-Sangihe Ridge. This collision probably began in the central Philippine region in the mid-Tertiary and has since been moving southward. The continuation of convergence between Philippine and Asian plates forced the creation of new subduction boundary along the eastern flank of the Philippine complex. At present this new boundary has propagated as far south as $2^{\circ} \mathrm{N}$, as shown by the bathymetric extent of the new Philippine Trench (Chase and Menard, 1969).

\section{COMPLEX NORTHERN AREA}

At least four submarine ridges and five basins form the complicated triangle between the West Philippine Basin, Palau-Kyushu Ridge, and the Ryukyu Trench (Figure 1). Most of these ridges seem to be convex toward the south, but the southernmost, the Oki-Daito Ridge, is either convex toward the north or linear. The Daito and Oki-Daito ridges abut the Palau-Kyushu Ridge at high angles and are apparently joined to each other and to the Amami Ridge by other ridge-like features (Chase and Menard, 1969; Harian, 1968).

Several characteristics point to a relatively great age of the complex. The depths of the basins, especially after the sediment fills and their loading effects are removed, approach those of the West Philippine Basin and of Mesozoic Pacific crust. Crustal heat-flow values average very close to those in old ocean floor (Watanabe et al., 1970), again implying antiquity. The thickness of sediments in several of these basins exceeds $1 \mathrm{~km}$ and, in general, is greater than elsewhere in the Philippine Sea (Figure 4). A working estimate of the age of this basin and ridge complex is late Mesozoic to earliest Tertiary.

The Oki-Daito Ridge bounds the West Philippine Basin along a slope which, although acoustically opaque, has a concave upward shape on several profiles that is reminiscent of volcaniclastic aprons (Figure 8; Harian, 1968). If such an apron does exist, then obviously it could not be older than the underlying basin, and very likely the responsible volcanism would be associated with the opening of the West Philippine Basin. Reworked pelagic Paleocene foraminifera in DSDP Holes $294 / 295$ most probably were derived from the Oki-Daito Ridge, suggesting a minimum age for that feature.

The Oki-Daito Ridge consists of two parallel subridges with a crude symmetry across the central trough (Figure 8; Harian, 1968). Seismic refraction measurements (Murauchi et al., 1968) outline a crust with island arc characteristics. Its relationship with the West Philippine Basin and its apparent northward convexity suggests that the Oki-Daito Ridge is a northfacing remnant arc. However, whether an entire arc system is present or not is uncertain because identification of tectonic units in the ridge area cannot be made. If it consists of only the rear flank of an arc system, it is difficult to see where the forward half could have gone. 


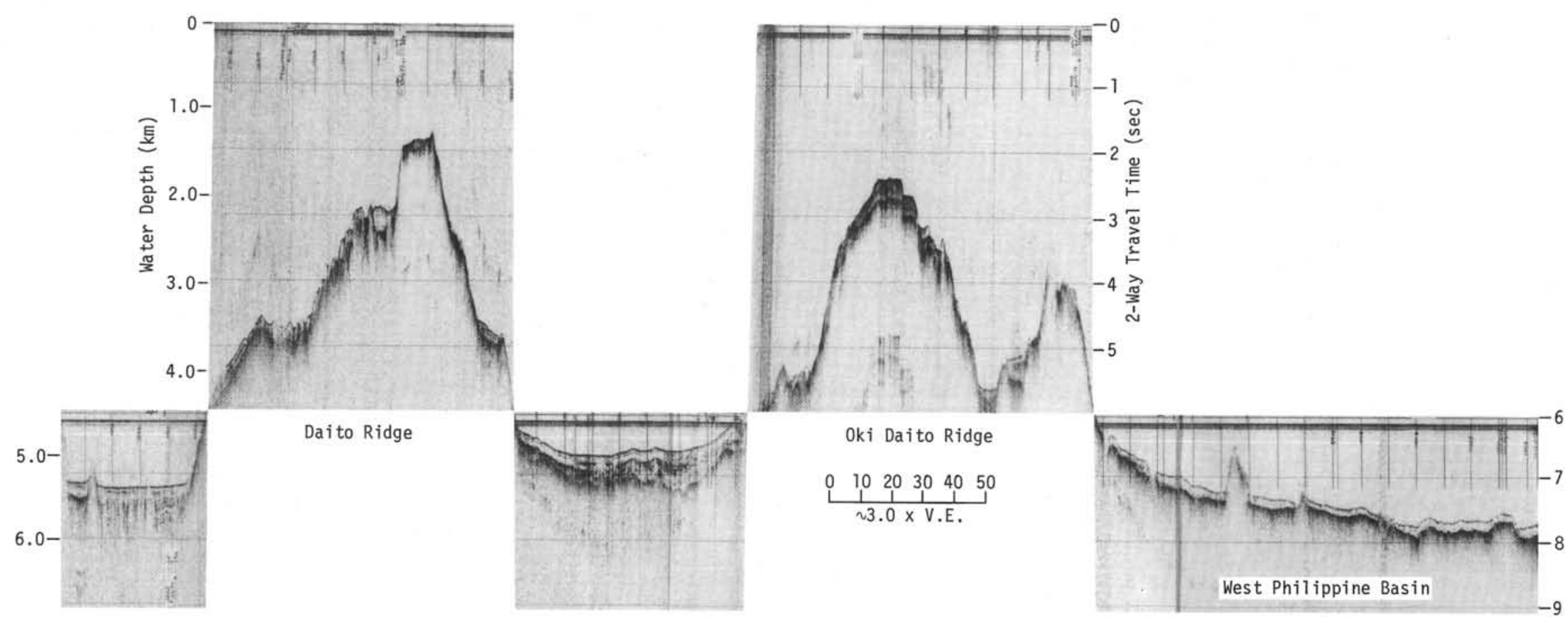

Figure 8. Glomar Challenger seismic reflection profile across the Oki-Daito and Daito ridges. The thicker sediments north of the Oki-Daito Ridge and the double nature of that ridge are clearly illustrated. 
In the Daito Basin to the north (Figure 8), the sediment fill is more than 600 meters thick. An uppermost transparent pelagic unit, 175 to 200 meters thick, probably represents deposition of brown clay during almost the entire Tertiary, if sedimentation rates from the West Philippine Basin can be extrapolated. Below these pelagics are additional sediments of uncertain character which are evidence of a yet earlier origin.

A 432-meter drill hole on Kita Daito Shima at the west end of the Daito Ridge penetrated 209 meters of Plio-Pleistocene and early Miocene reef limestone overlying calcareous clastics that are Chattian (late Oligocene) at the base of the hole (Hanzawa, 1940). Upgrowth and oscillation, rather than great subsidence marks the ridge history since the late Oligocene. The lack of volcanic material in the Kita Daito Shima hole points to tectonic quiescence at least since the midTertiary and suggests a greater age for the ridge. The present uplift of not only this island, but of two others on the west end of the Daito and Oki-Daito ridges, may be the effect of the arching of the Philippine plate over the outer swell of the Ryukyu Trench.

The identification of events and tectonic units in this and the more northerly part of the complex is not possible with available data. It is surmised that the region consists of a number of south-facing remnant arcs of late Mesozoic to earliest Tertiary age, as outlined previously.

\section{PALEOGEOGRAPHIC RECONSTRUCTION}

Enough data have been gathered in the Philippine Sea to attempt a reconstruction of the geologic history at least through the Neogene. Relative displacements within the Philippine "plate" (actually several plates) are more easily estimated than are motions between the Philippine plate and surrounding plates. Paleogene reconstructions are highly speculative, but are made to point out necessary constraints and relationships and to outline problems for future research.

There are at present three plates in the Philippine Sea, if a plate boundary is defined as a zone having relative displacement at least an order of magnitude greater than that within the plate. Most of the sea can be considered as the Philippine plate, but extension in the Mariana and Bonin arc systems requires the assumption of two more narrow plates or slivers between the extensional zones and trenches. It is uncertain that these narrow, and possibly thin lithospheric units, behave as internally rigid plates.

Extension in the Mariana Trough and Bonin zone seems to be in an east-west direction for the entire length of the two arc systems (Karig, 1971b; Karig and Moore, in preparation), but it is not possible to find a single pole of rotation with which to explain the observed amounts of extension. A single pole could account for the Bonin zone because the amount of extension is not determined, but no single pole seems capable of explaining the extensional geometry of the Mariana Trough. The Mariana arc might be deforming plastically at depth and along many surface faults. Alternatively, segments of the basin may be opening along transverse faults joining the ex- tensional zone to the trench (Bracey and Ogden, 1972), but no such zone has been documented.

There are great discrepancies in the EurasianPhilippine and Pacific-Philippine rotational poles thus far postulated. Morgan (in Le Pichon et al., 1973) placed the Philippine-Eurasian pole of rotation at $30^{\circ} \mathrm{N}$, $151^{\circ} \mathrm{E}$; but Fitch (1972) moved this pole to $56^{\circ} \mathrm{N}$, $154^{\circ} \mathrm{W}$ by assuming a rapid $(8 \mathrm{~cm} / \mathrm{yr})$ subduction rate in the Nankai Trough (Fitch and Scholz, 1971).

Results of Hole 298 and other relevant data show that the present rate is not likely to be much greater than 2 $\mathrm{cm} / \mathrm{yr}$ near the west end of that trench (Chapter 9, this volume), indicating that the pole lies much closer to Japan. Other geologic evidence for a pole near the northeast end of the Shikoku arc system is: (1) a rapid eastward decrease in the size of the accretionary prism along the arc (Figure 9), despite the eastward increasing proximity to sediment sources; and (2) late Tertiary displacement along the easternmost, Fuji Valley, sector of the arc system which can be measured in tens of kilometers (Matsuda, 1962). These data would provide only an average pole position during the Quaternary, but it is difficult to visualize the physical mechanism by which the rate of displacement along that plate boundary might double or more in 0.5 m.y.

A pole position at $36^{\circ} \mathrm{N}, 140^{\circ} \mathrm{E}$, with a rate of rotation of $14 \times 10^{-7} \mathrm{deg} / \mathrm{yr}$ (Table 1; Figure 10a) has been obtained using a $2 \mathrm{~cm} / \mathrm{yr}$ subduction rate at Site 298 and slip directions from Katsumata and Sykes (1969), Fitch (1972), and Kanamori (1971), and ignoring the motion along the Median Tectonic Line, which probably averages less than $0.5 \mathrm{~cm} / \mathrm{yr}$ (Okada, 1971). A necessary second displacement rate is obtained using the relationship between subduction rate and length of seismic zone (Isacks et al., 1968) at the south end of the Ryukyu Trench $(5 \mathrm{~cm} / \mathrm{yr})$ and the central Philippine Trench $(10 \mathrm{~cm} / \mathrm{yr})$. These values are admittedly very uncertain, but the calculated pole position is also quite insensitive to these values. Both assumed values give very similar pole positions.

The location of the Philippine-Pacific pole is also uncertain. It was placed at $7^{\circ} \mathrm{N}, 142^{\circ} \mathrm{E}$ by Katsumata and Sykes (1969); at $26^{\circ} \mathrm{S}, 143^{\circ} \mathrm{E}$ by Fitch (1972); at $5^{\circ} \mathrm{N}$, $145^{\circ} \mathrm{E}$ by Morgan (in Le Pichon et al., 1973); and at $6^{\circ} \mathrm{N}, 21^{\circ} \mathrm{W}$ by Solomon and Sleep (1974). A new Philippine-Pacific pole (Table 1) can be calculated by vectorally adding the Eurasian-Philippine pole determined above to the Pacific-Eurasian poles. The latter are deduced from global relative motion patterns or from focal mechanisms along the Japan Trench, lie at $4^{\circ} \mathrm{N}, 128^{\circ} \mathrm{E}$ and $3^{\circ} \mathrm{N}, 117^{\circ} \mathrm{E}$, respectively, and have an angular velocity of $15 \times 10^{-7} \mathrm{deg} / \mathrm{yr}$. Because it is more consistent with available focal mechanisms, the first of these poles is preferred.

Only a few appropriate focal mechanisms along the Bonin-Mariana subduction zone have been published, and these reflect the vector sum of motions between the two major plates and of extension within the arc systems. Focal mechanism 14 of Katsumata and Sykes (1969), which is the only adequate mechanism available along the Bonin trench, is reasonably consistent with the 

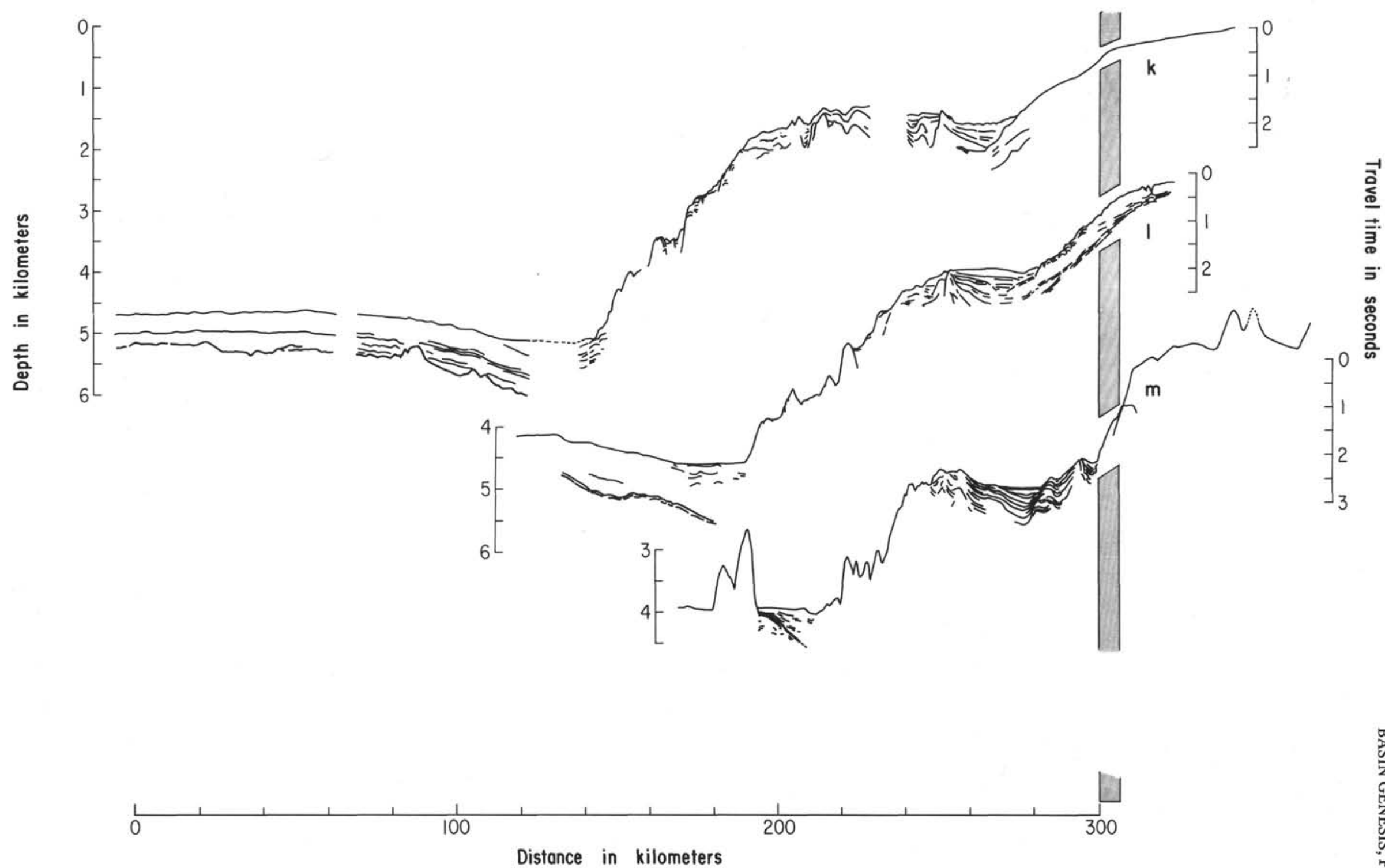

Figure 9. Line drawings of SIO and Seifu Maru (Maizuru Marine Observatory) seismic reflection profiles across the Nankai Trough showing the rapid eastward decrease in size of accretionary prism. Profile $\mathrm{k}$ crosses the trough near DSDP Hole 298 and profile $\mathrm{m}$ crosses at $137.5^{\circ} \mathrm{E}$. All profiles are oriented perpendicular to the trough axis, and are aligned along the upper slope discontinuity (gray bar). 

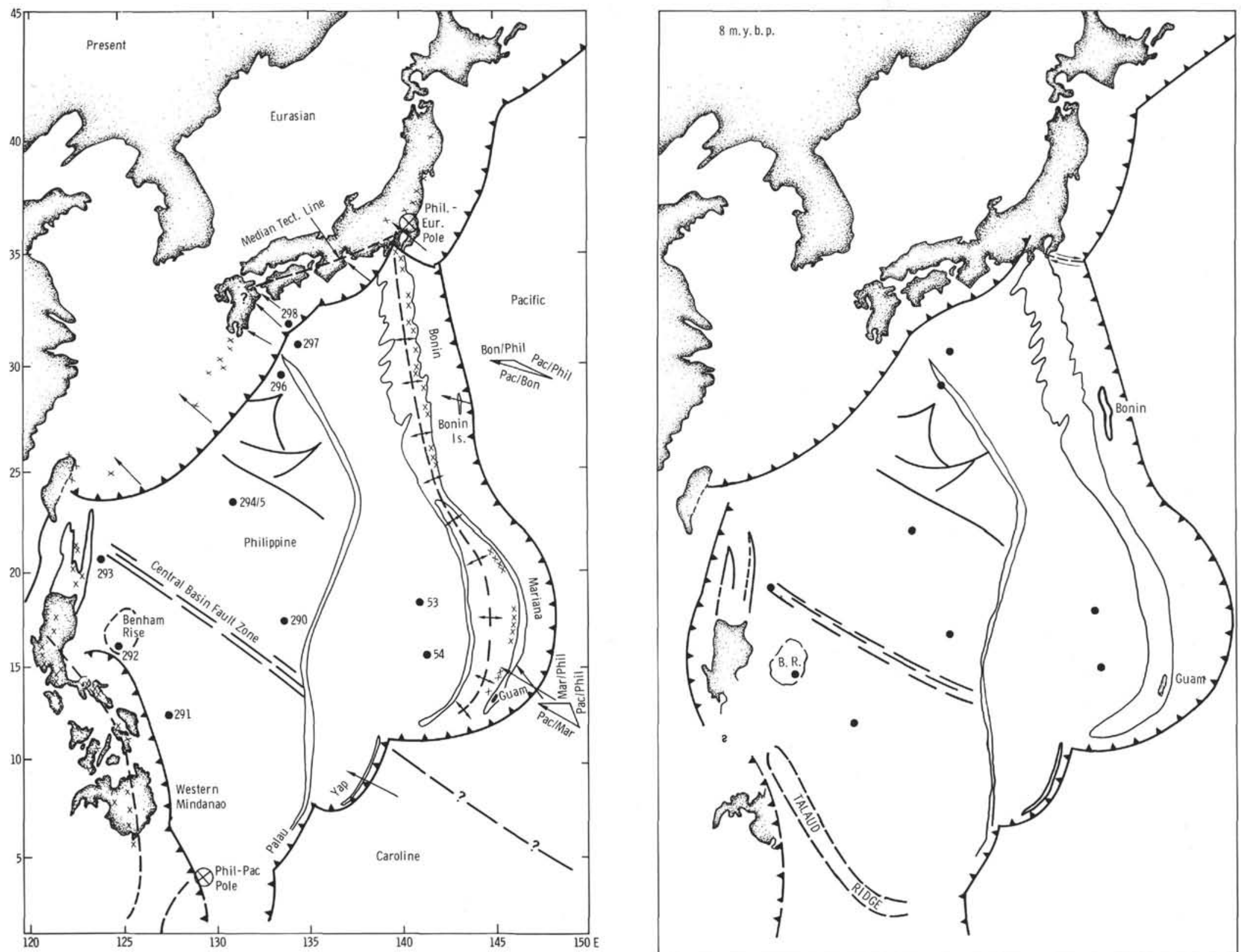

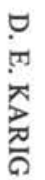

Figure 10. Paleogeographic reconstructions of the Philippine plate through most of the Tertiary. (a) Present. Instantaneous poles of rotation and applicable focal mechanisms (Katsumata and Sykes, 1968; Fitch, 1972) are indicated, together with vector triangles indicating effects of motion behind the trenches on the subduction displacement. (b) 8 m.y.b.p. (during relative quiet interval between volcanic pulses). Mariana trough has not yet opened and Talaud Ridge is beginning to collide with western Mindanao. 

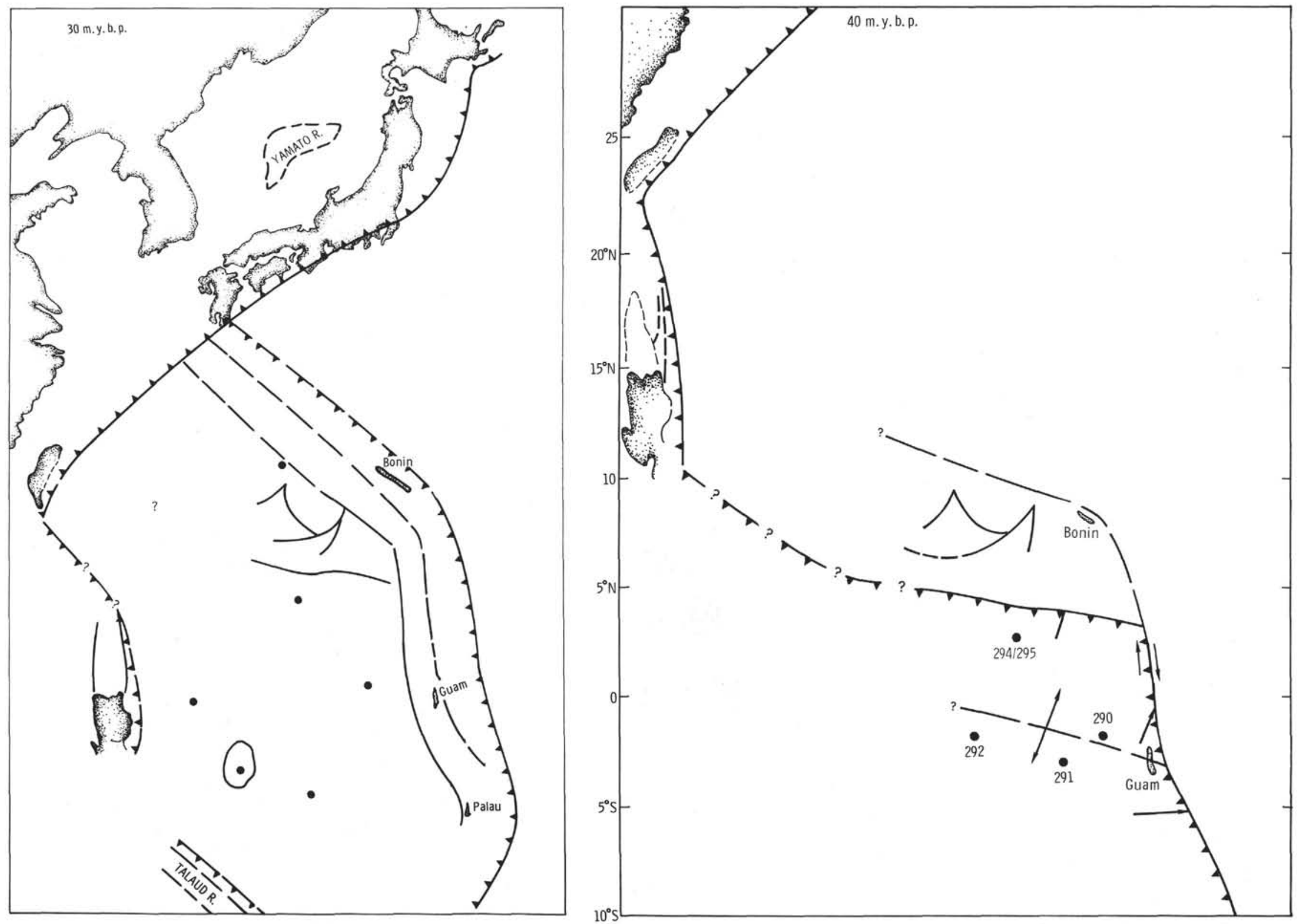

Figure 10. (Cont'd). (c) 30 m.y. (during relative quiet interval between Eocene and Miocene volcanic pulses). The Shikoku and Parece Vela basins are not yet open and the plate is oriented $20^{\circ}$ counterclockwise from its present position. (d) 40 m.y. (during opening of the West Philippine Basin). This highly speculative scenario has the West Philippine Basin opening behind the Oki-Daito and southern Palau-Kyushu ridges. Philippine plate is shown as moving northerly from the Philippine island region. 
TABLE 1

Poles of Relative Rotation for the Philippine Sea Area

\begin{tabular}{|c|c|c|c|}
\hline Pole & Position & Rate (deg/yr) & Basis or Reference \\
\hline Philippine-Asian & $36^{\circ} \mathrm{N}, 140^{\circ} \mathrm{E}$ & $14 \times 10^{-7}$ & $\begin{array}{l}2 \mathrm{~cm} / \mathrm{yr} \text { at Site } 298, \text { no } \\
\text { motion on Median } \\
\text { Tectonic Line }\end{array}$ \\
\hline \multirow[t]{2}{*}{ Pacific-Eurasian } & $65^{\circ} \mathrm{N}, 70^{\circ} \mathrm{W}$ & $9.1 \times 10^{-7}$ & Minster et al., 1974 \\
\hline & $64^{\circ} \mathrm{N}, 90^{\circ} \mathrm{W}$ & $8.9 \times 10^{-7}$ & Solomon and Sleep, 1974 \\
\hline Pacific-Asian & $58^{\circ} \mathrm{N}, 98^{\circ} \mathrm{W}$ & $9 \times 10^{-7}$ & $\begin{array}{l}4 \text { slip directions averaging } \\
299^{\circ} \text { at } 41^{\circ} \mathrm{N} \text { from } \\
\text { Kanamori, } 1971 \text {, } \\
\text { Shimazaki, } 1972 \text {, and } \\
\text { same rate as Pac/Eur } \\
\text { average }\end{array}$ \\
\hline \multirow[t]{2}{*}{ Philippine-Pacific } & $5^{\circ} \mathrm{N}, 128^{\circ} \mathrm{E}$ & $15 \times 10^{-7}$ & $\begin{array}{l}\text { Vector combination of } \\
\text { Phil/Asian and average } \\
\text { Pac/Eur }\end{array}$ \\
\hline & $3^{\circ} \mathrm{N}, 117^{\circ} \mathrm{E}$ & $15 \times 10^{-7}$ & $\begin{array}{l}\text { Vector combination of } \\
\text { Phil/Asian and Pac/Asian }\end{array}$ \\
\hline
\end{tabular}

preferred pole. Any east-west extension within the Bonin arc system, subtracted from the slip vector in the tranch would rotate the Pacific-Philippine component at that point clockwise (Figure 10a) and into even better agreement with this pole.

The rate of extension in the Mariana Trough apparently varies along trend from near zero at the north end to over $10 \mathrm{~cm} / \mathrm{yr}$ in the central section and back to a low rate at the south end. If extension is assumed to have been operative for at least 2 m.y., this motion, when added to the Pacific-Philippine slip vector, can explain the rapid southward decrease in both seismic activity and in the depth of the seismic zone south of $15^{\circ} \mathrm{N}$ (Katsumata and Sykes, 1969). Subtraction of this extension vector from the Pacific-Mariana motion, which has a direction given by focal mechanisms 18 and 19 of Katsumata and Sykes (1969), again results in a direction consistent with the predicted Philippine-Pacific pole (Figure 10a).

A very low level of shallow focus seismic activity and a lack of Quaternary volcanism characterizes the Yap and Palau island arcs, and could be attributed to slow subduction very near the rotational pole. A pole near to the trenches rather than parallel to them, as predicted using the pole of Katsumata and Sykes (1969). The one published shallow focal mechanism along the Yap and Palau arcs which indicated consumptive slip (Fitch, 1972) is in much better agreement with the pole at $128^{\circ} \mathrm{E}, 4^{\circ} \mathrm{N}$. An added complication along the south edge of the Philippine plate is a band of diffuse shallow seismicity along the Caroline Ridge (Katsumata and Sykes, 1969; Barazangi and Dorman, 1969) which suggests that the Yap and Palau arcs are not in contact with the Pacific plate, but with another plate. That plate, however, would seem to be moving very slowly with respect to the Pacific plate.

The present pulse of tectonism in the Philippine Sea can probably be associated with the upsurge in volcanic activity that has developed along the northern and eastern sectors of the sea since 5 m.y.B.P. (Donnelly, this volume). Other tectonism occurring around the periphery of the Philippine plate during this time include: the collision of the west-facing Luzon arc with Taiwan and the Ryukyu arc (Murphy, 1973; Biq, 1972; Karig, 1973), and the collision of the Talaud-East Mindanao Ridge with the east-facing Sangihe arc system. Stratigraphic sequences exposed on Taiwan and Okinawa provide clear evidence of the Luzon-TaiwanRyukuy collision (Ingle, Chapter 41, fig. 8-10, this volume) marked by staggered uplift and associated unconformities. Within the 5-m.y. duration of this volcanic pulse, extension in the Mariana Trough has occurred only during the last $2-3$ m.y.

In contrast to the $0-5$ m.y.B.P. volcanic pulse, the period from late middle Miocene to early Pliocene (approximately $5-10 \mathrm{~m} . \mathrm{y}$.) marks a minimum in volcanic activity along the Japan (Sugimura and Uyeda, 1973; Sugimura, in Donnelly, this volume) and MarianaBonin margins (Schlanger, 1964; Tracey et al., 1964). Geologic data from Luzon, Taiwan, and the Ryukyu arc are insufficient to show whether similar volcanic pulses, or perhaps pulses exactly out of phase from those on the eastern margin, have occurred. The late Tertiary geologic history of southwest Japan and the ash content in Hole 292 (Donnelly, this volume) suggest vague isochronous activity along the two margins.

It is unlikely that subduction has ceased during this interval along the Mariana-Bonin boundary, but it may have decreased in rate to account for the volcanic lull. The Nankai Trough was subducting sufficiently slowly in middle and late Miocene time that turbidites from Japan could cross the plate boundary (Chapter 9, this volume). The Philippine-Eurasian rotational pole is assumed to have remained near its present position for the past $10 \mathrm{~m} . \mathrm{y}$. because the Bonin-Japan junction has remained fixed and has undergone only minor compression during that time. The history of the Nankai Trough indicates that it had an average angular velocity 
significantly less than the assigned instantaneous rate. Such rotation should have caused a very slow southwestward migration of the Palau-Kyushu Ridge along the Nankai-Ryukyu subduction zone (Figure 10b).

Northeast Japan and the Bonin-Mariana-Yap arc systems displays a major pulse of volcanism from late Oligocene to mid-late Miocene (30-12 m.y.), peaking in the early Miocene as marked by the so-called "green tuffs" of northern Honshu (Ingle, Chapter 41, fig. 14, this volume). The definition of this pulse is based on land-based studies of Sugimura et al. (1963), Cloud et al. (1956), Tracey et al. (1964), Johnson et al. (1960), and on DSDP Holes 53 and 54 (Fischer, Heezen, et al., 1971) and Sites 290 and 296 (Chapters 2 and 7, this volume). Volcanic material at Sites 290 and 296 almost spans the Oligocene, and again suggests that minor activity typifies the intervals between pulses. A similar picture emerges from the study of Japanese volcanic history (Sugimura et al., and Sugimura in Donnelly, this volume). Miocene volcanism along the Ryukyu and Luzon arc systems may also belong to this pulse (Ingle, Chapter 41 , fig. 6, 8, and 10, this volume).

Both the Parece Vela and Shikoku basins opened from about 25 to 18 m.y.B.P., and during the peak of this mid-Tertiary volcanic pulse. Prior to this extension, it would appear that the combined Iwo Jima-PalauKyushu Ridge joined Japan near Kyushu and that the Bonin arc system migrated eastward. The south Fossa Magna, which marks the junction of the Bonin and southwest Japan arcs, first came into existence in the early Miocene (Matsuda, 1962), and began acting as a subduction zone in the middle Miocene. It was also about that time that the volcanic chain became restricted to the northeast Japan-Bonin trend. Previously, volcanism had also extended along the length of southwest Japan. Small, early to mid-Miocene, intermediate to silicic intrusives lying anomalously close to the Nankai Trough (Nozawa, 1968; Sugimura and Uyeda, 1973, p. 110) may have been emplaced at the northern end of the Bonin volcanic chain as it shifted eastward.

Continued clockwise rotation of both the BoninMariana lithospheric units and the Philippine plate during this pulse is suggested by. paleomagnetic data from Guam (Kobayashi, 1972; Reynolds, 1973). Both data sets indicate clockwise rotation of $50^{\circ}$ to $70^{\circ}$, but differ markedly in their measured inclinations. The $24^{\circ}$ downward inclination of Reynolds (1973) indicates no latitudinal shift. Both sample collections were obtained from the same locality that was mapped as Miocene (Tracey et al., 1964). Late Eocene microfossils from the same general outcrop at which the magnetic samples were collected (E. L. Winterer and R. E. Garrison, 1971, personal communication), put the age of these paleomagnetic vectors in doubt. Moreover, the measured rotation is due not only to rotation of the Philippine plate, but to opening of the Mariana arc (Kobayashi, 1972) and to possible drag alng the southern end of the Mariana arc (Reynolds, 1973). Approximately $45^{\circ}$ might be attributed to the differential rotation of the Mariana frontal arc and perhaps $15^{\circ}$ to rotation of the Philippine plate since the late Oligocene.
Although DSDP drilling failed in its objective to reach the basement in the Sea of Japan, the results obtained during Leg 31 (this volume) and an earlier analysis (Hilde and Wageman, 1973) suggest that at least the Yamato Basin formed during the late Oligocene to early Miocene tectonic pulse. This pulse also generated the extensive "green tuff" terrain along the east side of the basin and on the Yamato Rise (Chapter 13, this volume). Moreover, the paleobathymetric history of northwestern Honshu displays a similar pattern of basin development beginning in the early Miocene (Ingle, Chapter 41, fig. 12, this volume).

The en-echelon ridge-trough geometry of the Bonin arc is thought to have been generated at this time by the opening of the Japan Sea. This caused additional subduction along the Nankai trough, but also severe longitudinal compression of the more buoyant arc crust (Karig and Moore, in preparation). This model is based on similar arc deformation presently occurring in the Luzon arc as it collides end-on with the Ryukyu arc (Karig, 1973).

It is possible that deformation along the Central Basin Fault and development of the Caroline Ridge and of the Yap-Palau junction occurred during the late Oligocene (Fischer, Heezen, et al., 1971; Karig and Wageman, this volume). Why such interplate activity might have occurred is not known.

The amount of data with which to reconstruct the Philippine plate history decreases rapidly beyond the late Oligocene. Another volcanic minimum appears to center around the early late Oligocene (30-35 m.y.). Very few strata of this age have been identified on the islands around the plate periphery. The volcanic Fina-Sisu formation of Saipan, previously dated as Oligocene (Todd, 1957), has been redated as mid-Miocene (Todd, in Ladd, 1966); reinterpretation of those data suggests this unit encompasses the early-middle Miocene boundary and is correlative with the upper Umatac Formation of Guam (Ingle, Chapter 41, fig. 6, this volume). Slow deposition of late Oligocene nannofossil ooze and brown clay at Hole 290, which then lay close to the frontal arc, argues against uplift and erosion during the volcanic minimum and suggests that thin Oligocene deposits were removed by uplift associated with the early Miocene volcanism (Tracey et al., 1964).

During the early Tertiary subduction along most of the western margin of the Philippine plate and clockwise rotation of this plate with respect to an Asian plate probably occurred (Figure 10c), but the details of these movements cannot be determined. Some support for a northward shift and rotation of the Philippine plate is derived from analysis of the shape of Eocene magnetic anomalies in the West Philippine Basin (Louden, in preparation). If the Asian plate has been moving slowly southward during the Tertiary (McElhinney, 1973; Sugimura and Uyeda, 1973), then the West Philippine Basin and the complex area to the north would have been adjacent to a more southerly part of the PhilippineRyukyu boundary in the early Tertiary than at present.

Extensive mid- to late Eocene volcanism on the Bonin, Mariana, and Palau islands marks the peak of a third volcanic maximum in the Philippine Sea. Island geology (Cloud et al., 1956; Tracey et al., 1964) and 
Hole 290 show that this pulse declined in the early Oligocene. However, lack of observed strata in the region older than late mid-Eocene prevent the dating of the onset of volcanic activity (Ingle, Chapter 41, fig. 6, this volume). The best available data would place the opening of the West Philippine Basin during this volcanic pulse (approximately $36-42$ m.y.B.P.).

The geometry of the extensional development of the West Philippine Basin is not yet known. Apparently the basin was nearly surrounded by active or remnant arcs when extension ceased (Figure 10d). Late Eocene to early Oligocene volcaniclastic aprons lay behind the PalauKyushu Ridge and possibly behind the Oki-Daito Ridge. Magnetic anomalies southwest of the Central Basin Fault provisionally indicate spreading parallel to the Oki-Daito Ridge. North-northeast-trending basement lineations near the Palau-Kyushu Ridge and around the Benham Rise should have resulted from east-west extension or they could be very complex zones of transforms.

The Benham Rise was active and probably originated during the extensional opening of the West Philippine Basin as a shallow-water area associated with extrusion of tholeiitic basalt (Chapter 4 , this volume). Slow subsidence, probably a result of cooling, has marked its subsequent history. The known characteristics and behavior of the Benham Rise would identify it as a feature similar to the Manihiki, Hess, Shatsky, Magellen, and possibly Ontong-Java rises. If such rises could be related to active oceanic tectonic elements, one might point to melting anomalies along sections of spreading ridges (see Winterer et al., 1974).

The configuration of ridges in the western half of the Philippine Sea is not easily interpreted in terms of arc behavior. The T-junctions between the Palau-Kyushu ridge and the ridges of the older complex imply complicated arc kinematics.

Uyeda and Ben-Avraham (1972) have postulated that the West Philippine Basin formed along part of the Kula-Pacific accretionary plate boundary. In their model, the Palau-Kyushu Ridge was a long ridge-ridge transform on this boundary that was converted to an arc system by a change in motion direction of the Pacific plate about 40 m.y.B.P. Several observations render this model implausible.

The Bonin-Mariana-Palau frontal arc was already extruding shallow-water arc volcanics and collecting reef deposits in or before the late Eocene (Saito, 1962; Cloud et al., 1956; Tracey et al., 1964; Mason et al., 1956; Ingle, Chapter 41 , fig. 6 and 7 , this volume). Thus, this ridge, which was combined with the Palau-Kyushu Ridge at that time, was acting as an arc structure which reached sea level before extension ceased in the West Philippine Basin. Arc activity must have begun at least a few million years earlier. The Palau-Kyushu Ridge is far from orthogonal to the Central Basin Fault and is much less linear than known ridge-ridge transforms. The probable existence of an older arc complex north of the West Philippine Basin, especially that of a north-facing Oki-Daito Ridge, would require much more complicated plate behavior than that postulated by Uyeda and Ben-Avraham (1972).
Abnormally thin crust in the West Philippine Basin is similar to that in a number of other marginal basins (Parece Vela-Murauchi et al., 1968; China-Ludwig, 1970) and dissimilar to that in true oceanic areas, again arguing for extension behind arc systems. Uyeda and Miyashiro (1974) argue that the presence of a welldeveloped trench on the western boundary of the West Philippine Basin is difficult to explain if that basin were formed by extension behind an arc, but the Mariana and Parece Vela basins most probably also opened with trenches to either side. Moreover, it is not at all certain that there was an active trench along the west side of the West Philippine Basin at the time it was created.

If the West Philippine Basin opened as a marginal basin behind the Oki-Daito and Palau-Kyushu ridges (Figure 10d), then the T-junction where these two ridges join must be explained. The T-junctions exist in a number of contemporary arc settings. Some are nearly perpendicular trench-trench-trench triple junctions (Shikoku-Northeast Japan-Bonin). Others involve strike-slip faulting along the cap of the $\mathrm{T}$ (New BritainWest Melanesian-Solomon). Still others are probably a result of collision (New Britain-New Guinea). The Palau Kyushu-Oki Daito junction might have formed in any of these ways, but it is important to note that the observed configuration is not totally anomalous. What is strongly implied by the pattern is the existence, in prelate Eocene time, of a complex arrangement of island arcs and marginal basins in the region. Most likely this complex formed at a significantly lower latitude than that which it occupies at present and was part of the Indonesian-Philippine arc systems.

\section{OVERVIEW}

Perhaps the most significant result arising from the synthesis of data on the Philippine plate is the strong indication that the marginal basins opened rapidly during the height of volcanic pulses along the associated arc system (Figure 11). The Mariana Trough has been opening at rates up to $10 \mathrm{~cm} / \mathrm{yr}$ or more during the last $2-3$ m.y. Only slightly less tightly constrained evidence indicates that the combined Parece Vela-Shikoku basin opened from approximately 25 to $18 \mathrm{~m} . y$. B.P. at rates near $10 \mathrm{~cm} / \mathrm{yr}$. The spread of basement ages in the West Philippine Basin suggests a period of extension from about $45-37$ m.y.B.P. If the duration of these episodes is approximately correct, then extension occurred in the Philippine Sea about one-third of the time from midEocene to present (Figure 11). Insufficient data exist to justify any cyclic nature to the extensional episodes, but if such were the case, a cycle would be about 20 m.y. long.

Arc volcanism along the eastern periphery of the plate has also been uneven in intensity through the Tertiary, but volcanic pulses were much longer than the extensional episodes (Figure 11). Pulses probably represent changes in rate of eruption rather than total cessation of volcanism. The significance of changing rates of volcanic extrusion along the convergent plate margins is not satisfactorily understood, but it is commonly assumed that the intensity of arc volcanism is crudely proportional to rate of subduction. Another possible 


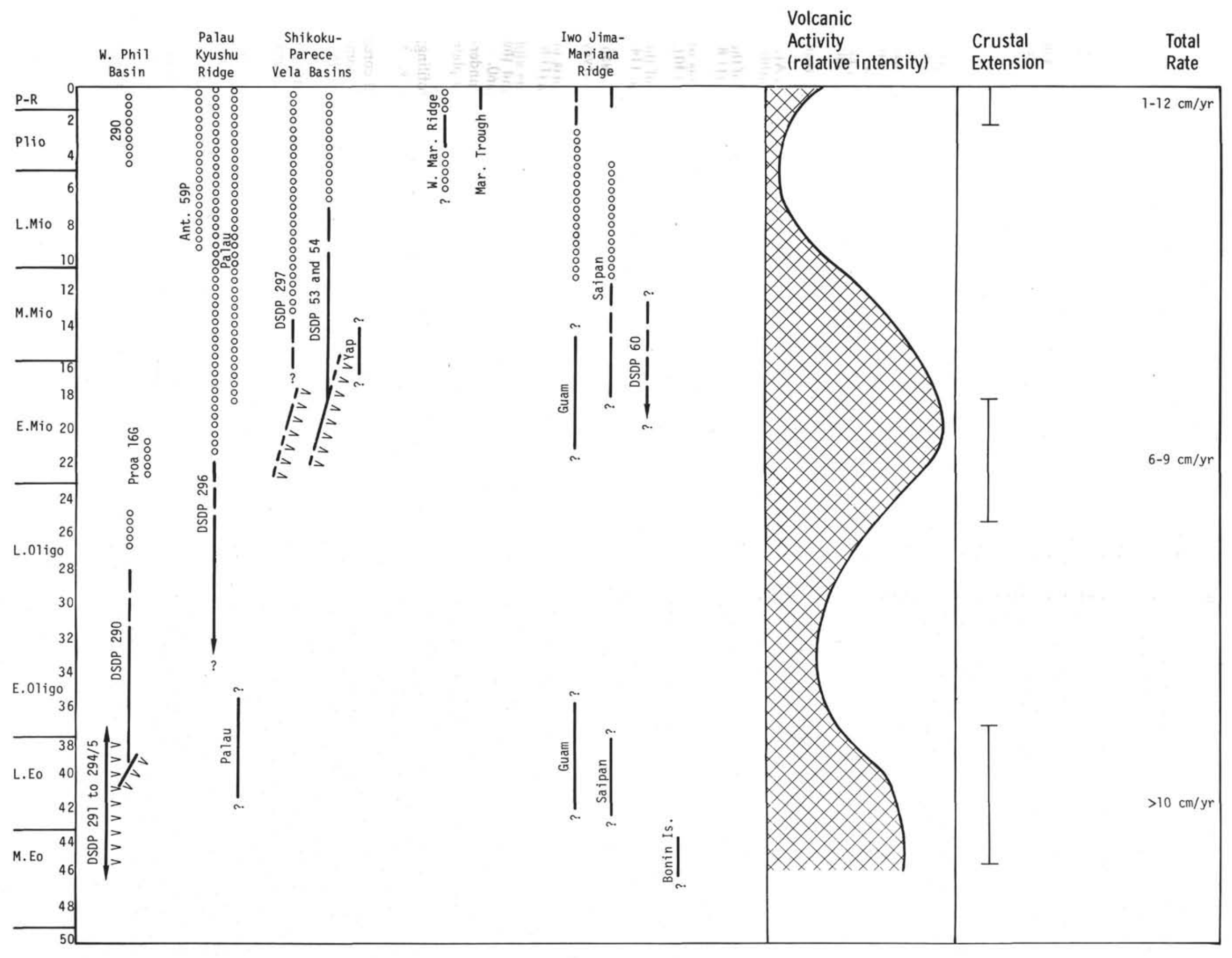

Figure 11. Correlation diagram showing observed periods of volcanic and extensional activity at points within the Philippine plate. These show the eastward progression and timing of extensional and volcanic pulses associated with subduction along the eastern boundary of the plate for the past 45 m.y. 
cause of variations is a change in the amount of fusible material, but it is not easy to see how this would occur during the Tertiary along the Bonin-Mariana boundary, except as a result of changing subduction rate.

Neither is it known how much lag time there might be between changes in subduction rate and its effects on intensity of volcanism. Slow subduction in the Nankai Trough since the mid-Miocene has not yet produced a new volcanic chain. Volcanism could also be expected to persist, at least in diminishing intensity, several million years after subduction ceases.

The correlation of extensional episodes with subduction pulses, through an intermediate correlation of both with arc volcanism, is thus not yet well constrained. Supporting evidence for this relationship is the observation that active marginal basins occur behind rapidly subducting plate margins with the possible exception of extension in the Scotia arc, which may be driven by plate edge effects.

If marginal basin extension is a result of upwelling mantle originating from the downgoing lithosphere, then the observed extension rates are far too great to permit a steady-state system (see Karig, 1971a, p. 25572558). A modification of this idea is that the heated mantle that is generated along the seismic zone during rapid subduction is trapped beneath the upper plate and collects until forces associated with this buoyant mass overcome resisting stresses in the lithosphere. Piercement of the overlying lithosphere and extension could occur when subduction rates decreased, or when changes in nearby plate boundary conditions reduced stresses along the boundary in question. Extension may occur very rapidly as the gravitationally unstable mass of heated mantle rises and cools to create new lithosphere. Cessation of extension in this scheme would occur when the supply of unstable mantle was exhausted. The thin crust of the Philippine Sea basins may in some way be a result of this rapid extension associated with active diapirism.

The relationship of arc-related geologic activity to global schemes of relative plate motions and to motions in a reference frame fixed to the deep mantle is an intriguing problem requiring much attention. It has been approached in the Philippine Sea by Uyeda and Miyashiro (1974), but before useful answers can emerge, the evolution of the arc systems and the kinematics of plates in global schemes must be independently determined. Our knowledge of the Philippine plate geology has been advanced a great distance by work on the peripheral islands, by marine geophysical surveys, and by deep-sea drilling. However, we still cannot adequately construct a flow sheet relating the temporal and spatial relationships among events associated with subduction. The mere validity of such a flow sheet to replace the orogenic cycle might be questioned. One of the most important tasks remaining in our understanding of orogenesis is to collect sufficient detailed information in various arc systems in order to generate the relationships mentioned above.

\section{ACKNOWLEDGMENTS}

My several cruises and related studies in the Philippine Sea were supported by the National Science Foundation under grant GA-22696 (Menard-Karig); GA-35990 and GA-38107.

\section{REFERENCES}

Barazangi, M. and Dorman, J., 1969. World seismicity map of ESSA coast and geodetic epicenter data 1961-67: Seis. Soc. Am. Bull., v. 59, p. 369.

Barazangi, M., Pennington, W., and Isacks, B., in press. Global study of seismic wave attenuation in the upper mantle behind island arcs using P waves: J. Geophys. Res.

Ben-Avraham, Z., Bowin, C., and Segawa, T., 1972. An extinct spreading centre in the Philippine Sea: Nature, v. 240, p. $453-455$.

Biq, C. C., 1972. Dual trench structure in the Taiwan-Luzon region: Geol. Soc. China, Proc., v. 15, p. 65-75.

Bracey, D. R. and Ogden, T. A., 1972. Southern Mariana Arc: Geophysical observations and hypothesis of evolution: Geol. Soc. Am. Bull., v. 83, p. 1509-1522.

Burns, R. E., Andrews, J. E., et al., 1973. Initial Reports of the Deep Sea Drilling Project, Volume 21: Washington (U.S. Government Printing Office).

Chase, T. E. and Menard, H. W., 1969. Bathymetric atlas of the northwestern Pacific Ocean: H.O. Publ. 1301, Washington (U.S. Naval Oceanog. Off.).

Christian, L. B., 1964. Post Oligocene tectonic history of the Cagayan basin, Philippines: Philippine Geol., v. 18, p. 114 147.

Cloud, P. E., Schmidt, R. B., and Burke, H. W., 1956. Geology of Saipan, Marianas Islands: U.S. Geol. Survey Prof. Paper 280-A.

Fischer, A. G., Heezen, B. C., et al., 1971. Initial Reports of the Deep Sea Drilling Project, Volume 6: Washington (U.S. Government Printing Office).

Fitch, T. J., 1972. Plate convergence, transcurrent faults and internal deformation adjacent to southeast Asia and the western Pacific: J. Geophys. Res., v. 77, p. 4432-4460.

Fitch, T. J. and Scholz, C. H., 1971. Mechanism of underthrusting in southwest Japan: a model of convergent plate interactions: J. Geophys. Res., v. 76, p. 7260-7292.

Harian, A. M., 1968. Bathymetry and subbottom profiling; Marine Geophysical Program 65-67 Area 12, v. 3: Washington (U.S. Naval Oceanog. Off.).

Hanzawa, S., 1940. Micropaleontologic studies of drill cores from deep well in Kita-Daito Shima: Jubilee publ. in commemoration of Prof. H. Yabe's 60th birthday, v. 2, p. 755 802.

Hart, S. R., Glassley, W. E., and Karig, D. E., 1972. Basalts and sea floor spreading behind Mariana island arc: Earth Planet. Sci. Lett., v. 15, p. 12-18.

Hilde, T. W. C. and Wageman, J. M., 1973. Structure and origin of the Japan Sea. In Coleman, P. J. (Ed.), The western Pacific: Nedlands (Univ. Western Australia Press), p. 415-434.

Isacks, B., Oliver, J., and Sykes, L. R., 1968. Seismology and the new global tectonics: J. Geophys. Res., v. 73, p. 55055900.

Johnson, C. G., Alvis, R. J., and Hetzler, R. L., 1960. Military geology of Yap Islands, Caroline Islands: prepared under the direction of the Chief of Engineers, p. 163.

Kanamori, H., 1971. Great earthquakes at island arcs and the lithosphere: Tectonophysics, v. 12, p. 187-198. 
Karig, D. E., 1971a. Origin and development of marginal basins in the western Pacific: J. Geophys. Res., v. 76, p. 2542-2561. 1971b. Structural History of the Mariana island arc system: Geol. Soc. Am. Bull., v. 82, p. 323-344.

1973. Plate convergence between the Philippines and the Ryukyu islands: Marine Geol., v. 14, p. 153-168.

Karig, D. E. and Anderson, R. N., in preparation. Mode of extension in the Mariana Trough, Philippine Sea.

Karig, D. E. and Glassley, W. E., 1970. Dacite and related sediment from the west Mariana Ridge, Philippine Sea: Geol. Soc. Am. Bull., v. 81, p. 2143-2146.

Karig, D. E. and Moore, G. F., in preparation, Tectonic complexities in the Bonin island arc system: Tectonophysics.

Karig, D. E. and Sharman, G. F., III, in pres. Subduction and accretion in trenches: Geol. Soc. Am. Bull., v. 85.

Katsumata, M. and Sykes, L. R., 1969. Seismicity and tectonics of the western Pacific: Izu-Mariana, Caroline and Ryukyu-Taiwan regions: J. Geophys. Res., v. 74, p. 59235948.

Kobayashi, K., 1972. Reconnaissance paleomagnetic and rock magnetic study of igneous rocks of Guam, Mariana and related sites. In Hoshino, H., and Aoki, H. (Eds.), Izu Peninsula: Tokyo (Tokai Univ. Press), p. 385-390.

Kuno, H., 1962. Catalog of the active volcanoes of the world; Japan, Taiwan, and Mariana: Internatl. Volcanol. Assoc., Naples, Italy, p. 245-252.

Ladd, H. S., 1966. Chitons and gastropods (Haliotidae through Adeorbidae) from the western Pacific Islands: U.S. Geol. Survey Prof. Paper, 531, 98 p.

Lair, C. and Sanko, P., 1969. Core analysis and bottom photographs; Marine Geophysical Survey Program 65-67, Area 12, v. 5: Washington (U.S. Naval Oceanogr. Off.).

Lee, C., and Hilde, T. W. C., 1971. Magnetic lineations in the Western Philippine Sea: Acta Oceanogr. Taiwanica, n. 1, p. 69-76.

LePichon, X., Francheteau, J., and Bonnin, J., 1973. Plate Tectonics, Amsterdam (Elsevier Scientific Publ. Co.).

Louden, K. E., in preparation, Magnetic anomalies in the West Philippine Basin: J. Geophys. Res.

Ludwig, W. J., 1970. The Manila Trench and West Luzon Trough-III: Seismic refraction measurement: Deep-Sea Res., v. 17, p. 553-571.

McElhinney, M. W., 1973. Paleomagnetism and plate tectonics of eastern Asia. In Coleman, P. J. (Ed.), The western Pacific; island arcs, marginal seas, geochemistry: Perth (Univ. Western Australia Press).

Mason, A. C. et al., 1956. Military geolog of Palau Islands and Caroline Islands: U.S. Army, Chief Eng., Intell. Div. Office Eng. Headquarters, U.S. Army Force Far East.

Matsuda, T., 1962. Crustal deformation and igneous activity in the South Fossa Magna, Japan. In Macdonald, G. A. and Kuno, H. (Eds.), Am. Geophys. Union, Geophys. Mono. 6, p. 140-150.

Meledres, M. M. and Comsti, F., 1951. Reconnaissance geology of southeastern Davao: Philippine Geol., v. 5, p. 38-46.

Minster, J. B., Jordan, T. H., Molnar, P., and Haines, E., 1974. Numerical modelling of instantaneous plate tectonics: Geophys. J. Roy. Astron. Soc., v. 36, p. 541-576.

Murauchi, S., Den, N., Asano, S., Hotta, H., Yoshii, T., Hagiwara, K., Ichikawa, K., Sato, T., Ludwig, W. J., Ewing, J. I., Edgar, N. T., and Houtz, R. E., 1968. Crustal Structure of the Philippine Sea: J. Geophys. Res., v. 73, p. 3142-3171.

Murphy, R. W., 1973. The Manila Trench-West Taiwan fold belt: a flipped subduction zone: Geol. Soc. Malaysia Bull., v. 6 , p. $27-42$.
Nozawa, T., 1968. Radiometric ages of granitic rocks in the outer zone of southwest Japan and its extensions: 1968 summary and north-shift hypothesis of igneous activity: J. Geol. Soc. Japan, v. 74, p. 485-489 (in Japanese with English abstract).

Okada, A., 1971. Active faulting of the Median Tectonic line: Kagaka, v. 41, p. 666-669 (in Japanese).

Ranneft, T. S. M., Hopkins, R. M., Albert, J. R., Frohlich, J., and Gwinn, J. W., 1960. Reconnaissance geology and oil possibilities of Mindinae: Am. Assoc. Petrol. Geol. Bull., v. 44 , p. $529-568$.

Reynolds, R., 1973. Paleomagnetism of Miocene volcanics of Guam and the curvature of the southern Mariana Island Arc: Am. Geophys. Union Trans., v. 54, p. 254 (abstract).

Saito, T., 1962. Eocene planktonic foraminifera from Hahajima (Hilsborough Island): Paleontol. Soc. Japan, Trans. Proc., no. 45, p. 209-225.

Schlanger, S. O., 1964. Petrology of the limestones of Guam. U.S. Geol. Survey Prof. Paper 403-D.

Sclater, J. G., 1972. Heat flow and elevation of the marginal basins of the western Pacific: J. Geophys. Res., v. 77, p. 5705-5719.

Shimazaki, K., 1972. Focal mechanism of a shock at the northwestern boundary of the Pacific plate: extensional feature of the continental lithosphere: Phys. Earth Planet. Interiors, v. 6, p. 397-404.

Solomon, S. C. and Sleep, N. H., 1974. Some simple models for absolute plate motions: J. Geophys. Res., v. 79, p. $2557-$ 2567.

Sugimura, A., Matsuda, T., Chinzei, T., and Nakamura, K., 1963. Quantitative distribution of late Cenozoic volcanic materials in Japan: Volcanolol. Bull., v. 26, p. 125-140.

Sugimura, A Uyeda, S., 1973. Island arcs: Japan and its environs; developments in geotectonics: New York (Elsevier Scientific Publishing Co.).

Todd, R., 1957. Smaller foraminifera. In Geology of Saipan, Mariana Islands, pt. 3 (Paleontology), USGS Prof. Paper 280-H, p. 265-286.

Tomoda, Y., Kobayashi, K., Segawa, J., and Nomura, M., 1973. Magnetic anomalies in the Shikoku Basin, Northern Philippine Sea, Abstract, IAGA Conf. Kyoto, Japan.

Tracey, J. I., Schlanger, S. O., Stark, J. T., Doan, D. B. and May, H. G., 1964. General geology of Guam: U.S. Geol. Survey Prof. Paper 403-A.

Tsuya, H., 1937. On the volcanism of the Huzi volcanic zone, with special reference to the geology and petrology of Idu and the southern islands: Tokyo Univ., Earthquake Res. Inst. Bull., v. 15, p. 216-357.

U.S. Dept. of Commerce, E.S.S.A., 1969. International Indian Ocean expedition, USC \& GS Ship Pioneer 1964. Bathymetric, geomagnetic and gravity data, Volume 3: Washington (U.S. Government Printing Office).

Uyeda, S. and Ben-Avraham, Z., 1972. Origin and development of the Philippine Sea: Nature Phys. Sci., v. 240, p. 176-178.

Uyeda, S. and Miyashiro, A., 1974. Plate tectonics and the Japanese Islands: A synthesis: Geol. Soc. Am. Bull., v. 85,

Watanabe, T., Epp, D., Uyeda, S., Langseth, M., and Yasui, M., 1970. Heat flow in the Philippine Sea: Tectonophysics, v. 10, p. $205-22$

Watts, A. B. and Weissel, J. K., 1974. Magnetics lineations in the Shikoku Basin, South of Japan: Geol. Soc. Am. Abstracts with programs v. 6, p. 1001.

Winterer, E. L., Lonsdale, P. F., Matthews, J. L., and Rosendahl, B. R., 1974. Structure and acoustic stratigraphy of the Manihiki Plateau: Deep-Sea Res., v. 21, p. 793-814. 